\title{
İslam Eserlerinde Kullanılan Altıgen Tabanlı Geometrik Desenlerin Çözümlenmesine Yönelik Yeni Bir Yaklaşım
}

\begin{abstract}
Öz: Geometrik süslemeler tarihin hemen her döneminde kullanılmıştır. İslam eserlerinde Emevi, Abbasi, Karahanl, Gazneli ve Büyük Selçuklu dönemlerinde geliştirilmiş, coğrafi bölge ve kullanılan malzemenin türüne bağlı olarak bu alanda farklı biçimlerde ortaya çıkmıştır. İran bölgesinde özellikle tuğla malzemeyle uygulanan kompozisyon biçimleri, Anadolu'ya taşındığında daha çok taş malzemeyle uygulanmıştır. Taşın yanında ahşap ve çinide de geometrik motifler önemli örneklerle zenginleşerek devam ettirilmiştir. Bezemenin her alanında hemen her malzemeyle uygulanmış olan geometrik kompozisyonlar bitkisel, yazı ve figürlü kompozisyonlar ile birlikte Selçuklu, Beylikler ve Osmanlı devirleri boyunca varlığını kesintisiz olarak sürdürmüştür. İslam eserlerinde kullanılan geometrik desenler kare, beşgen, altıgen, yedigen, sekizgen, dokuzgen, ongen, on altıgen, yirmi dörtgen, daire gibi birbirinden farklı geometrik şekillerden oluşur. Konumuzla ilgili yapılmış herhangi bir envanter çalışması olmadığı için bazı kaynak kitaplardan ve internet sayfalarından elde edilen verilerden hareketle Fas, Hindistan, İran, İspanya, Misır, Özbekistan, Suriye, Türkiye ile İngiltere'deki bazı müze ve kütüphanelerde tespit edilen toplam 223 eserdeki 39 farklı geometrik desen, 13 grup halinde incelenmiştir. Çalışmamızın sınırları gereği kronoloji, coğrafi konum ya da kullanılan malzeme farkı gözetilmeksizin sadece altıgen tabanlı geometrik desenler şekil bakımından incelenmiştir. Bu desenleri daha pratik olarak çizmek için tarafımızdan altıgen tabanlı yeni bir ızgara sistemi oluşturulmuştur. Bahsi geçen yeni yaklaşım budur. Ayrıca birbirine benzer ya da birbirinin varyasyonu kabul edilebilecek desenler gruplandırılmış, ortaya konulan yeni ızgara vasıtasıyla desenlerin çizimleri gösterilmiştir. Makalenin sınırları gereği detaylı desen analizi yapılamamış, sadece desenlerin ızgaraya yerleşme biçimi gösterilmiştir.
\end{abstract}

\section{Halil librahim ERYILMAZ}

Anahtar Kelimeler: İslam Eserleri, Desen, Geometrik Desen, Altıgen, Altıgen Izgara.

\section{A New Approach for The Analysis of Hexagonal-Based Geometric Patterns Used in Islamic Works}

\section{Bahar SELIMGIL"}

\begin{abstract}
Geometric ornaments have been used in almost every period of history. It was developed in the periods of Umayyad, Abbasi, Karakhanid, Gazneli and Great Seljuk in Islamic art and different forms emerged depending on the geographical region and the type of material used. The composition forms applied especially with brick material in the Iranian region were mostly applied with stone materials when they moved to Anatolia. In addition to stone, geometric motifs in wood and tiles continued to be enriched with important examples. In addition to the geometric compositions, herbal, writing and figured compositions applied with almost every material in every aspect of decoration, it continued its existence uninterruptedly throughout the Seljuk, Principalities and Ottoman periods. The geometric patterns used in Islamic works consist of different geometric shapes such as square, hexagon, pentagon, decagon, octagon, twenty quadrilaterals, circular. Since there is no inventory study on our subject, we have taken action with the data we have obtained from some source books and internet pages. Accordingly, Morocco, India, Iran, Spain, Egypt, Uzbekistan, Syria, 39 different geometric patterns in a total of 223 works identified in some museums and libraries in the UK and Turkey, were investigated in 13 groups. In this study, only geometric patterns with hexagonal base were examined in terms of shape, regardless of chronology, geographical location or the material used. A new grid system with hexagonal base has been created to draw these patterns more practically by us. In addition, the detailed drawings of the patterns are shown through the new grid created by grouping the patterns that are similar to each other or can be considered as variation of each other. Detailed pattern analysis could not be made due limitations of the article, only shown that patterns are placed on the grid.
\end{abstract}

Keywords: Islamic Artifacts, Pattern, Geometric Pattern, Hexagonal, Hexagonal Grid.

* Dr. Öğr. Üyesi İzmir Kâtip Çelebi Üniversitesi, İslami İlimler Fakültesi, İslam Tarihi ve Sanatları Bölümü, Türk İslam Edebiyatı ve İslam Sanatları Anabilim Dalı. E-Posta: halilibrahim.eryilmaz@ikc.edu.tr ORCID ID: https://www.orcid.org/0000-0002-5973-9972

** Yüksek Lisans Öğrencisi. İzmir Kâtip Çelebi Üniversitesi, Sosyal Bilimler Enstitüsü, İslam Tarihi ve Sanatları Anabilim Dalı. E-Posta: baharselimgil@gmail.com ORCID ID: https://www.orcid.org/0000-00024146-4499 


\section{Giriş}

Türk-İslam eserlerinin süslemeleri dekoratif ve uygulama açısından farklılık içerdiğinden genellikle figür (insan ve hayvan motifleri), bitkisel, yazı ve geometrik bezeme olmak üzere dört başlık altında ele alınmıştır.' Bazı süslemelerde bunların bir arada kullanıldığı da görülmektedir. Hatta geometrik ve bitkisel süslemenin bir arada kullanıldığı, sonsuza giden, karmaşık ve anlaşılması zor olan süslemeler Arabesk olarak adlandırılmıştır. ${ }^{2}$ Geometrik süsleme dışında kalan diğer süslemelerin farklı özelliklere sahip olması, işlev ve uygulama aşamasında farklı hususları içermesinden dolayı çalışmamızda sadece geometrik süsleme ele alınmıştır.

Türk-İslam dünyasında var olan hayvan ve insan tasvirine karşı soğuk tutum, yeni konulara ve çizgi türlerine yönelime sebep olmuştur. Bu sayede, hayal gücü ve hendese biliminin birleşmesiyle geometrik kompozisyonlar özgün bir süsleme haline gelmiştir. Boşluk korkusu olarak da ifade edilen, dik açılı veya yıldız motifli şekiller bakımından zengin, karmaşık geometrik kompozisyonlar ortaya çıkmıştır. ${ }^{3}$ Arabesk süslemenin uygulamada yoğun kullanımı bu korkuyu destekler niteliktedir. $^{4}$

İslam coğrafyasında eser üretenler tasvir yasağı bağlamında tasvirden yani insan ve hayvanların resimlerini, heykellerini yapmaktan uzak durmuşlardır ki bu da geometrik desen oluşturmada ilerlemeye sebep olmuştur. ${ }^{5}$ Geometrik düzenlemelerde sistem evrenin matematiği kadar karmaşık, temel figürler temel gerçekler kadar sade ve berraktır. Yıldız merkez etrafındaki ritmik uyum, evrensel düzenin ritmidir. ${ }^{6}$

Tasavvufun yaygın olduğu dönemlerde geometrik tezyinat İslam eserlerinde hâkim süsleme unsuru olmuştur. Vahdet-i vücut nazariyesinin de etkisiyle geometrik desenlerdeki düzen ve ahenk, her şeyin tam, ölçülü ve muazzam bir Bakanlığı Yayınları, 1982), 7.

2 Selçuk Mülayim, Türk Sanatında Ikonografik Dönüşümler Değişimin Tanıkları, (İstanbul: Kaknüs Yayıncilık, 2015), 245.

3 Selçuk Mülayim, Geometrik Kompozisyonların Çözümlenmesine Bir Yaklaşım, Sanat Tarihi Dergisi, 1 (1982), 51.

4 Oliver Leaman, İslam Estetiğine Giriş, (İstanbul: Küre Yayınları, 2019), 69.

5 Mülayim, Anadolu Türk Mimarisinde Geometrik Süslemeler, 68.

6 Semra Ögel, Anadolu Selçuklu Sanatı Üzerine Görüşler, (İstanbul: Matbaa Teknisyenleri Basımevi, 1986), 98. 
mükemmellikte yaratılmış olduğunu ve böylesi bir düzenin de sadece tek bir yaratııı vasıtasıyla sağlanabileceğini ifade etmiştir.'Geometrik desenlerin onlara bakan gözlere hatırlattığı şey yaratııının tek olduğudur. Bununla birlikte, matematiksel uyum, tabiattaki maddenin diyalektiği, malzemenin orijinal yapısından ve tekniğinden hareketle geometrik kompozisyonların işlevsel yönüne dikkat çeken görüşler de mevcuttur. ${ }^{8}$ Örneğin geometrik desenler ile maddenin moleküler düzeydeki içyapısında yer alan kristaller kıyaslanarak aralarında bir benzerlik kurulmaya çalışılmıştır. ${ }^{9}$ E. Makovisky, Paul J. Seinhardt ve Peter J. Lu çini örneklerini inceleyerek çini süslemelerdeki yarı-kristallerin yapısına tam olarak benzeyen, şerit örgü olarak bilinen, beşgenlerden ve ongenlerden oluşan motifleri keşfettiklerini ileri sürmüşlerdir. İslam matematikçileri yaptıkları çalışmalarla geometrinin gelişmesinde önemli katkılar sağlamıştır. Ancak matematikçiler ile özellikle geometri ile ilgilenenlerle sanatçılar arasında nasıl bir ilişki olduğu bugün bilinmemektedir. ${ }^{10}$

Geometrik düzenlemelerin kuruluşlarında yer alan temel figürlere tarih boyunca çeşitli anlamlar yüklenmiştir. Üçgen, Aşkın ile beşer arasında bağlantı unsuru veya bilinç ve ahengin vasıtası kabul edilmiştir. ${ }^{11}$ Kare, adaletin sembolü sayılmış ayrıca dört unsurla (ateş, hava, su ve yer) ilişkilendirilmiş, özellikle yeryüzünün değişmez sembolü olmuştur. Dikdörtgen, din, ilim, adalet ve hakikati; sekizgen, sonsuzluğu temsil etmiştir. ${ }^{12}$ Allah'a varış (menzil), gökyüzü ve sonsuzluk sembolü sayılan daire, evrendeki düzeni, birliği ve bütünlüğün ifadesi kabul edilmiştir.13 Ayrıca küp: yer; piramit: ateş; üçgen prizma: hava; on ikiyüzlü prizma: kozmos; yirmi yüzlü prizma: suyun sembolü kabul edilmiştir. ${ }^{14}$

Geometrik desenlerin kökeniyle ilgili olarak, bu desenlerin Büyük Selçuklu döneminde gelişerek Azerbaycan ve İran üzerinden, Türklerin Anadolu'ya gelmeleriy-

9 Serap Ekizler Sönmez, Mimar Sinan Camileri ve İslam Sanatında Geometrik Desenler, (İstanbul: Klasik Yayınları, 2017),43. Dönemi Kazı Sonuçları ve Sanat Tarihi Araştırmaları Sempozyumu Kitabı içinde. Bu bildiri, 17-19 Ekim 2007 tarihleri arasında XI. Ortaçag-Türk Dönemi Kazı Sonuçları Ve Sanat Tarihi Araştırmaları Sempozyumu'nda sunulmuştur. (İzmir: Ege Üniversitesi Basımevi, 2009), 296-303.

11 Ahmet Çaycı, İslam Mimarisinde Anlam ve Sembol, (Konya: Palet Yayınları, 2017), 66.

12 Çaycı, İslam Mimarisinde Anlam ve Sembol, 70-71.

13 Beşir Ayvazoğlu, Aşk Estetiği, 121; Semra Ögel, Anadolu Selçuklu Sanatı Üzerine Görüşler, 95, 101. 
le birlikte Anadolu'ya ulaştığı ileri sürülmektedir. ${ }^{15}$ Necipoğlu ve bazı Batılı araştırmacılara göre ise geometrik süslemenin kökeni Abbasilere dayanmaktadır. ${ }^{16}$ Tahran'daki İslam müzesinde bulunan IV-V. yüzyıllara tarihlenen alçı tekniğiyle yapılmış kare tabanlı bir geometrik desen örneği aslında geometrik süslemenin kökeninin İslamiyet öncesine kadar gidebileceği konusunda bize ipucu vermektedir. ${ }^{17}$ Bu konuda daha kesin bilgilere ulaşabilmek için arkeolojik çalışmaların artmasına ve geometrik süsleme buluntularının detaylı incelenmesine ihtiyaç vardır.

Türk-İslâm sanatının karakteristik görünüşlerinden biri olan geometrik süslemelerin İslam kültürünün egemen olduğu bütün coğrafyalarda, farklı tekniklerle, taş, çini, tuğla, ahşap, minyatür, cilt, tezhip gibi çok farklı malzemeler üzerinde uygulandığı görülmektedir. ${ }^{18}$ Şam Ulu Camii'nin (715) batı girişindeki mermer pencere şebekelerindeki yarım daire kemerin ayırdığı yüzey bütünüyle geometrik bir kompozisyonla ağ gibi kaplanmıştır. Mermer şebekelerde ise; düşey ve diyagonal düz çizgiler, "S" biçimli kıvrımlar ve daire yaylarından oluşturulmuş altı dilimli yoncalar görülmektedir. Bu motifler İslam sanatının en eski tarihli, önemli geometrik örnekleri kabul edilmektedir. Kahire İbn Tulun Camii geometrik kompozisyonlarında görülen dik ve çapraz eksendeki daire veya altıgen unsurlar geometrik süslemede özel bir yer tutmaktadır. ${ }^{19}$

Tunus, Kayrevan'daki Seydi Ukba Camii'nin (867) ahşap minberinde olağanüstü incelikte geometrik motiflerin çeşitliliği bulunmaktadır. Yıldız, haç, gamalı haç ve sekizgen geçmelerle oluşturulan düzenlemeler, daire biçimleri, yonca ve zengin bitki süslemeler IX. yüzyıl Abbasi çağının ahşap geometrisinin zenginliğini göstermektedir. $^{20}$

Harrekan'daki 1067 ve 1093 tarihli iki kümbette görülen örneklerde tuğlalar düz derzli sade diziler ve çok çeşitli geometrik kompozisyonlar yapacak biçimde örülmüştür. İran bölgesinde, özellikle Azerbaycan bölgesindeki Kümbed-i Surh (1147) ve Kümbed-i Kebud'da (1196) geometrik kompozisyonlar karmaşıklaşmış ve renk unsurunun da eklenmesiyle zenginleştirilerek Anadolu'ya örnek olacak eserler meydana getirilmiştir. ${ }^{21}$

Mülayim, Anadolu Türk Mimarisinde Geometrik Süslemeler, 93 Sönmez, İslam Sanatında Geometrik Desenler, 23. Bkz. https://patterninislamicart.com/archive/1/tim006 Yıldız Demiriz, İslam Sanatında Geometrik Süsleme, (İstanbul: Hayalperest Yayınevi, 2017), 10. Mülayim, Anadolu Türk Mimarisinde Geometrik Süslemeler, 16-17. Mülayim, Anadolu Türk Mimarisinde Geometrik Süslemeler, 17. Mülayim, Anadolu Türk Mimarisinde Geometrik Süslemeler, 17. 
Orta Asya, Anadolu Türk mimarisinin gelişmesinde önemli bir yer tutmaktadır. Anadolu'daki önemli eserlerde görülen birçok geometrik kompozisyonun kaynağı Orta Asya mimari süslemeleridir. Özkent, Buhara, Semerkant gibi şehirlerdeki eserlerde kullanılan bazı teknik ve motifler özellikle Karahanlılar aracılığıyla zenginleşerek İran üzerinden Anadoluıya geçmiştir.22

Geometrik süslemenin çok zengin örneklerine Anadolu Selçuklu sanatında rastlamak mümkündür. Selçuklular geometrik geçme ağ, örgü, yıldız gibi çeşitli geometrik motifleri mimaride, halıda, çinide, ahşapta ve kitap sanatlarında severek kullanmışlardır. ${ }^{23}$ Anadolu Selçuklu sanatında geometrik motifler vazgeçilmez bir süsleme unsuru olarak dış malzemede taş, iç malzemede ise mozaik çini üzerinde uygulanmıştır. ${ }^{24}$ Anadolu taş işşiliğinde görülen geometrik kompozisyonlar, geçme ağlar, bordürler, kufi yazılar vb. desenler, İran Selçuklu mimarisindeki tuğla süslemesinin taşa uygulanmış biçimidir. Ancak geometrik desenler taş malzemenin yapısı nedeniyle farklı bir kimlik ve görünüş kazanmıştı. ${ }^{25}$ Örneğin Divriği Kale Camii ve Sitte Melik Türbesi'nin portallerinde görülen geometrik örneklerde tuğla etkisi çok belirgindir. XIII. yüzyıl sonuna doğru geometrik desenler bitkisel motifler ile aynı yüzeyler üzerinde kaynaştırılarak kullanılmıştır. Bu yüzyılda, Sivas Keykavus Şifahanesi'nin (1217) türbe kasnağında yer alan altıgen ve on iki kollu yıldızlardan oluşan kompozisyonlar önemli bir gelişmedir. ${ }^{26}$

XIV. yüzyıl, mimari süslemede sadeliğin tercih edilmeye başlandığı bir dönemdir. Önceki yüzyıl süslemelerinde çokça kullanılan bazı geometrik desenlerden bitkisel motiflere doğru bir değişim söz konusudur. Portal ve mihraplarda yer alan geometrik süslemeler yerine bitkisel süslemeler yer almaya başlamış, geometrik süslemeler ikincil yapı unsurlarında kullanılmıştır. ${ }^{27}$

Osmanlı döneminde geometrik bezemenin önemini yitirdiğine dair bir yanlış görüş söz konusudur. Hâlbuki geometrik motifler yoğun olarak kullanılmakla kalmamış, motiflerin çeşitliliği de artmıştır. ${ }^{28}$ Osmanlı süslemelerinde geometrik 
motifleri meydana getiren ana çizgi veya prensipler çok daha sade ve basittir. Dahası bu dönemde de geometrik desenler tezhip, ahşap, çini, cild ve minyatürlerde yer almıştır. ${ }^{29}$ Geometrik motiflerin Osmanlı mimarisinde değişik mimari elemanlarda kullanımı söz konusudur. Ahşap kapı kanatları, pencere kepenkleri, taş, mermer ve bronz şebekelerde geometrik formlar ince bir işçilikle uygulanmıştır. Kompozisyonlarda ise çokgenlerin kenar sayısı artmış, dairesel yaylardan meydana gelen geometrik formlar sık görülmeye başlamıştır. Özellikle Osmanlı ahşap işçiliğinde kullanılan geometrik desenler son günlerine kadar büyük bir özen ve incelikle devam etmiştir. ${ }^{30}$

\section{1.İslam Eserlerinde Kullanılan Geometrik Desenler}

Geometrik süslemenin bütün İslam coğrafyasında birçok teknikle, çok farklı malzemelere uygulandığı görülmektedir. Bu çeşitlilik, zor ve karmaşık gibi görünen geometrik desenlerin sanılanın aksine, çiziminde ve uygulanmasında basit ve esnek bir yöntem izlendiğinin bir göstergesidir.

Geometrik desenleri incelediğimizde ilk bakışta karmaşık görünür fakat detaylı olarak bakıldığında aslında daha basit şekillerin birbirini tekrar etmesiyle oluştuğu fark edilir. Bu durum matematikçilerin de zaman zaman vurguladığı bir durumdur; karmaşık şekiller daha küçük ve basit şekillerin çeşitli biçimlerde birleşmesi ile oluşur. ${ }^{31}$ Öyleyse geometrik desenleri incelemeye desenin kendini tekrar etmeyen en basit şeklini ele alarak başlamalıyız. Bu basit şekilleri (üçgen, kare, beşgen gibi) incelerken matematikten yararlanmak zorundayız. Matematik hayatın birçok alanında olduğu gibi (mühendislik, mimarlık, zanaat, medya vs.) mimari süslemelerde de baş aktördür. Tarihte İslam coğrafyasındaki eserlerde uygulanan geometrik desenler de matematik bilimi sayesinde oluşturulmuştur ve bu desenlerde gelişmiş bir matematik kullanıldığı açıkça görülmektedir.

İslam eserlerinde kullanılan geometrik desenlerin ortak özelliği olarak, desenin kendini tekrar etmeyen en küçük bölümünün çizildiğini ve sonrasında farklı açılarda farklı yönlere ayna simetrisi denilen yöntemle çoğaltıldığını söyleyebiliriz. $\mathrm{Bu}$, desenin çizilirken kullanıldığı açılara bağlı olarak kare tabanlı, beşgen tabanlı ya da altıgen tabanlı olmasına göre 4 yöne, 5 yöne ya da 6 yöne simetrik olarak kopyalanıp çoğaltılmasıdır. Böylece desen sonsuza kadar çoğaltılıp, büyütülebilir. 


\subsection{Altıgen Tabanlı Izgara ve Türevi}

İslam eserlerinde kullanılan geometrik desenlerle ilgili çalışmalar az olsa da bu konuya olan ilgi günümüzde gittikçe artmaktadır. Bu konuda son dönemde yapılan çalışmalarda çeşitli tekniklerle (ızgara, poligon, nokta birleştirme gibi) geometrik desenler analiz edilmeye çalışılmaktadır. Fakat bu çalışmalarda desenlerin bulunduğu eserlerin yapıldığı dönemin koşulları göz ardı edilmektedir. Hâlbuki günümüzde bilgisayar kullanılarak çizilen bu desenlerin o dönemlerde (VIII. ve IX. yüzyıl) ne şekilde çizildiği, hangi ebatlarda ve nasıl uygulandığı sorularının cevabı tam olarak verilememektedir. Burada önemli olan geometrik desenlerin analizinin yapılıp, çizilebilmesi değil, uygulandığı dönemin koşullarında ne şekilde çizildiği, nasıl ve hangi ebatlarda uygulandığıdır. Bunu tespit edebilmek için detaylı bir kaynak araştırması yapmak elzemdir. Geometrik desenler konusunda özellikle İslam eserlerinde kullanılanlar hakkında yapılan çalışmalar oldukça azdır. Yazılı kaynak olarak sadece 3 adeti parşömen rulo, 2 âdeti de yazma eser olmak üzere toplam 5 farklı eser bulunmaktadır. Bunlar:1. Sanatkârların ihtiyacı olan geometrik konstrüksiyonlar hakkında kitap - Kitâb fîmâ yahtâcu ilayhi el-sânî' min a'mâl el-hendese, Ebü'l Vefâ el-Bûzcânî (farklı nüshaları mevcut); 2. Taşkent Parşömenleri (Doğu Araştırmaları Enstitüsü ); 3. Mirza Akbar Parşömenleri (Victoria \& Albert Müzesi, Londra); 4. İç içe geçen benzer veya karşılıklı şekiller hakkında, Fî tadakhul el-eşkâl el-müteşâbihe ev mütevâfike, Anonim, Farsça, 40 varak (Bibliotheque Nationale, Paris); 5. ve son kaynak eser ise çalışmamıza da ana kaynak teşkil eden Topkapı Parşömeni'dir (Topkapı Saray Müzesi Kütüphanesi). ${ }^{32}$

Bu konuda hazırlanmış en geniş kapsamlı kaynak olarak Gülru Necipoğlu tarafından 1995 yılında yayınlanan Topkapı Scroll-Geometry and Ornament in Islamic Architecture adlı kitabı söyleyebiliriz. Bu kitapta geometrik desenlerin tarihsel sürecinden bahsedilirken ayrıca geometrik desenlerin nasıl çizildiğine dair önemli ipuçları veren parşömen rulolar hakkında da detaylı bilgiler yer almaktadır. Bu rulolar Topkapı Parşömeni, Taşkent Parşömeni ve Mirza Akbar Parşömeni'dir. İslam eserlerinde kullanılan geometrik desenleri analiz edebilmek için ilk bakılması gereken kaynaklar bu rulolardır.

İçeriğindeki ızgara çizimleri dolayısıyla Topkapı Parşömeni üzerinde duracağız. Bu çalışmanın merkezinde yer alan Topkapı rulosu, türünün en iyi korunmuş örne- 
ğidir. Bu parşömen İslam eserlerinde yer alan geometrik desenler ile geometrik desenlerin uygulanması noktasında geniş kapsamlı bir bakış açısı sunmaktadır. Topkapı Sarayı Kütüphanesi envanterinde M. 1956 numarasıyla kayıtlı olan, yaklaşık 29.5 metre uzunluğunda ve $33 \mathrm{~cm}$ genişliğindeki bu parşömende kare ve dikdörtgen çerçeveli 114 adet çizim bulunmaktadır. Bu parşömenin XV-XVI. yüzyıllar arasında İran`da hazırlandığı tahmin edilmektedir. ${ }^{33}$ Fakat parşömenin ne zaman ve nerede hazırlandığı hakkında veya Osmanlı devleti hazine koleksiyonuna ne şekilde girdiğine dair herhangi bir yazı, tarih veya özel işaret bulunmamaktadır. ${ }^{34}$ Topkapı Parşömeni'nde yer alan geometrik desenler, çeşitli ızgara sistemleri ile oluşturulmuştur. Bu desenler siyah mürekkeple ve bir kamış kalemle çizilmiş; bazıları kırmızı mürekkeple ya da farklı renklerle vurgulanmıştır (Fotoğraf 1).

Topkapı Parşömeni'nde ayrıca üçgen ızgaralar üzerinde kaligrafik yazı ve geometrik desenli çizimler de bulunmaktadır. Bu makalenin konusunu oluşturan altıgen tabanlı geometrik desenlerin oluşumuna ışık tutacak olan bu çizimlerdir.

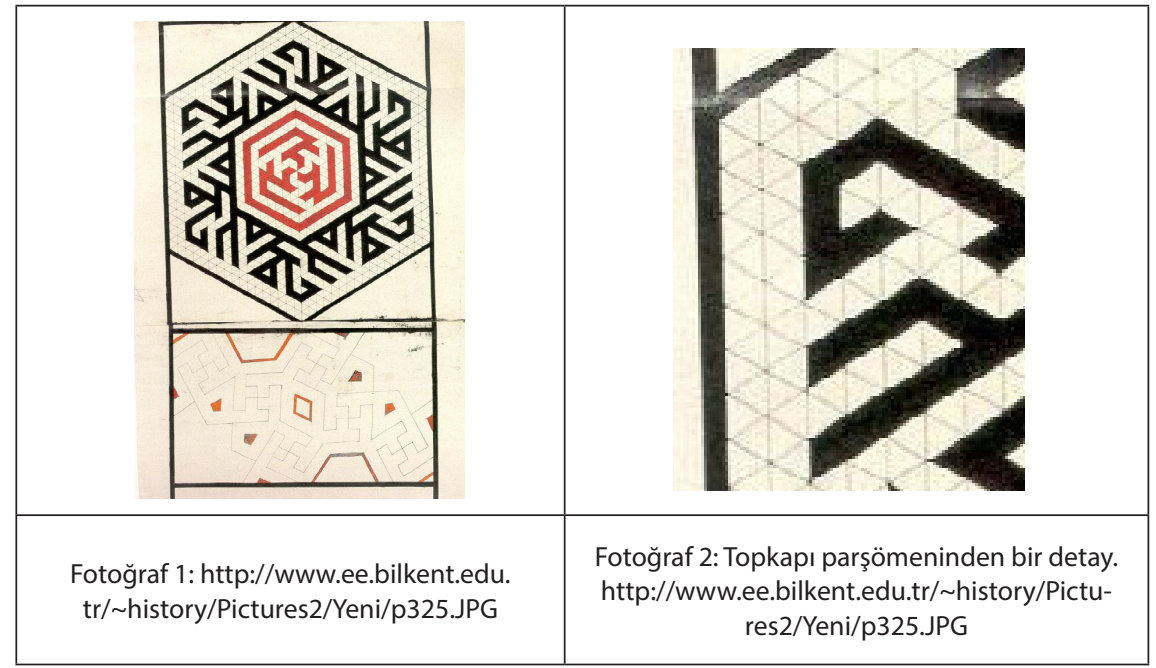

Topkapı parşömeninde yer alan çizimler, altta eşkenar üçgenlerden oluşan ızgara ve onun üzerindeki üçgenler takip edilerek siyah ve kırmızı renkle oluşturulan kaligrafik yazı ve desenler diğer altıgen tabanlı desenlerin oluşumuyla

34 Gülru Necipoğlu, The Topkapı Scroll-Geometry and Ornament in Islamic Architecture, ( New York: The Getty Center, 1995), 44; Şen, "İslam Sanatında Geometrik Desenler", 106. 
ilgili önemli ipuçları vermektedir (Fotoğraf 1, Fotoğraf 2). Burada dikkat edilmesi gereken desenin üçgenler üzerinden devam ettirildiğidir ki bu da desenin boyutunun üçgenin boyutuna bağlı olması demektir. Yani üçgenin eşkenarlarını hangi ölçüde çizersek desen de o oranda meydana gelmektedir. Deseni küçültmek istediğimizde de altta yatan ızgarada yer alan üçgeni küçültmemiz yeterli olacaktır. Bu da desenleri herhangi bir eserde, herhangi bir ebatta, istediğimiz gibi uygulamaya olanak vermektedir. Illave olarak tek ve aynı ızgaradan her türlü kompozisyonun çıkarılabileceği hatta bu ızgara kullanılarak daha önce hiç örneği görülmemiş farklı desenlerin de oluşturulabileceği dikkate alınmalıdır.

Topkapı Parşömen'indeki çizimlerde sadece eşkenar üçgenlerden oluşan bir ızgara kullanıldığı ortaya çıkmaktadır ${ }^{35}$ (Çizim 1 ve Çizim 2). Bazı desenler oluşturulan bu ızgaraya tam olarak yerleşmektedir (Çizim 3). Fakat altıgen tabanlı olmasına rağmen bazı desenlerin bu ızgaraya tam olarak uymadığı görülmektedir (Çizim 4). Nitekim bu ızgaraya yerleşmeyen altıgen tabanlı desenlerin çizimini bazı araştırmacılar daire çizerek ve nokta birleştirme yöntemiyle oluşturmaya çalışmışlardır ${ }^{36}$ (Fotograf 3). Fakat bu yöntem oldukça zahmetli ve karmaşık bir işlemdir. Ayrıca deseni başka bir zamanda ya da başka bir eserde farklı bir ebatta tekrar etmek istediğimizde her defasında daire çizme yöntemiyle yeniden oluşturmak durumunda kalırı ki bu işlem uygulama safhasında ciddi zaman ve emek kaybına neden olacaktır. Fakat 60-60-60 derecelik eşkenar üçgenlerden oluşan bu ızgaradan hareketle (Çizim 7), 30-60-90 derecelik dik üçgenlerle yeni bir ızgara oluşturduğumuzda altıgen tabanlı desenlerin bu yeni ızgaraya tam olarak yerleştiği gözlemlenmiştir (Çizim 5). Bu ızgaranın oluşturulmasında karelerden de yararlanmak mümkündür. ${ }^{37}$ Çizim 6 'da görüldüğü üzere uzun dik kenarı 7 birim kare, kısa kenarı 4 birim kare şeklinde bir 30-60-90 derecelik dik üçgen hazırlayabiliriz. Bu dik üçgenleri yan yana ayna simetrisi ile birleştirdiğimizde yaklaşık olarak bir eşkenar üçgen oluşturabiliriz. Böylece tüm yüzeyi kaplayabilir ve ızgaramızı oluşturabiliriz ${ }^{38}$ (Çizim 8). Bazı araştırmacılar tarafından daire yöntemiyle çizilmeye çalışılan kimi desenlerin de oluşturmuş olduğumuz bu ızgaraya tam olarak yerleştiği aşağıda verilen 3e Grubunda görülmektedir ${ }^{39}$ (Fotograf 3, Çizim 20).

Sönmez, İslam Sanatında Geometrik Desenler, 125-127.

Eric Broug, İslam Sanatında Geometrik Desenler, (İstanbul: Klasik Yayınları, 2016), 37-40.

Sönmez, İslam Sanatında Geometrik Desenler,137.

Metin Arık, Mustafa Sancak, Pentapleks Kaplamalar, (Ankara: Tübitak Kitaplar Müdürlüğü, 2012), 3. Bkz. 3E grubu. 


\section{MÎZÂNÜ'L-HAK}

ISLAMI ILIMLER DERGISI

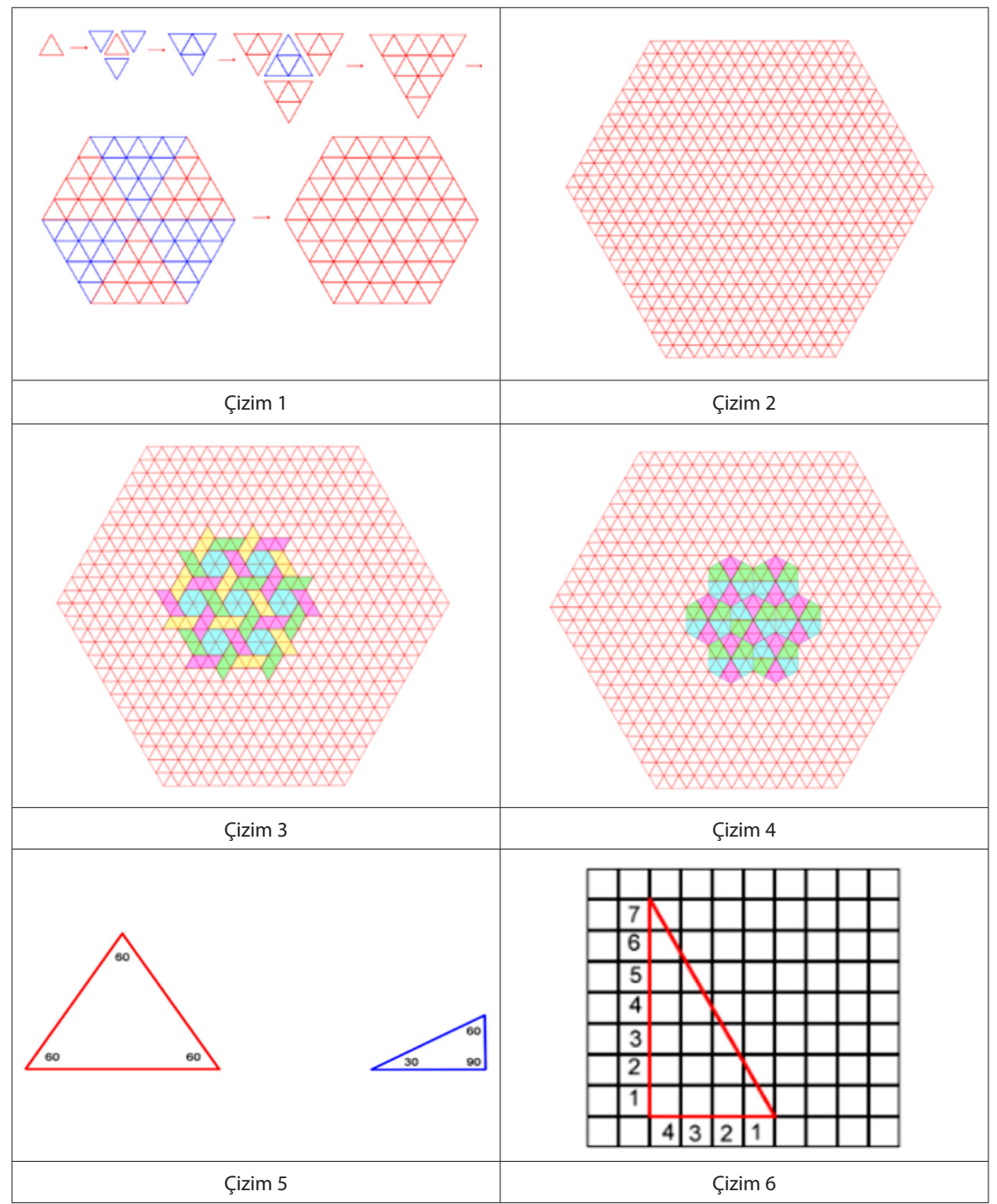


Halil İbrahim ERYILMAZ, Bahar SELIMGiL

İslam Eserlerinde Kullanılan Altıgen Tabanlı Geometrik Desenlerin Çözümlenmesine Yönelik Yeni Bir Yaklaşım

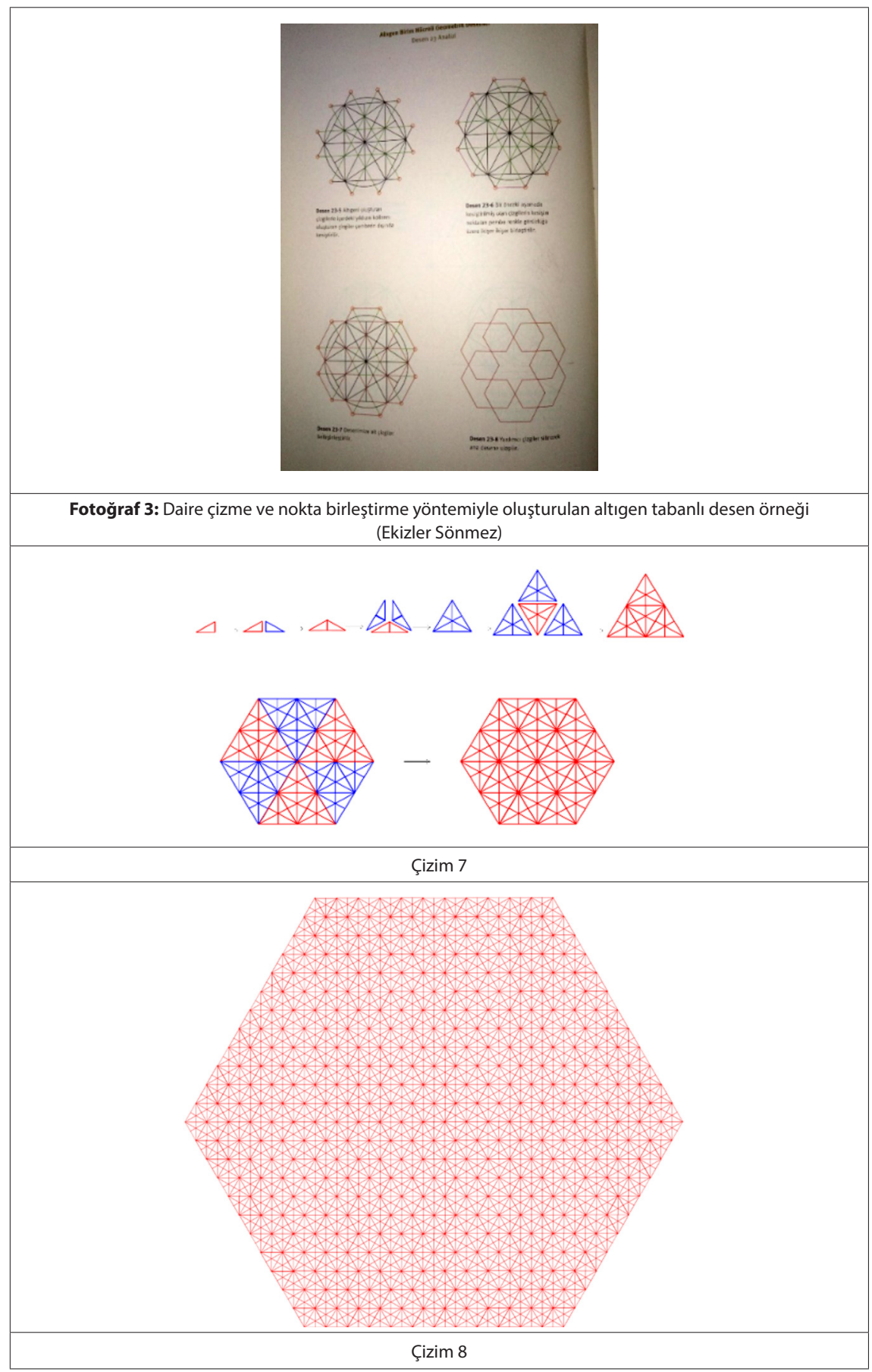


Makalenin sınırları gereği her bir desen için ayrı ayrı desen analizi yapma imkânı olmadığı için sadece 5c Grubundan Çizim 26'da yer alan desenin analizini vermekle yetineceğiz. Bu desende, ızgaraya yerleşme biçimine göre önce altı köşeli yıldız şeklini çizdik, ardından yıldızın etrafına dolanan şekli altı adet olarak yerleştirdik. En son, altı adet küçük paralelkenar şekilleri köşelere çizdikten sonra bir altıgen elde ettik. Bu elde ettiğimiz altıgen, desenin kendini tekrar etmeyen en küçük birimidir. Bu çalışmamızda da ele aldığımız tüm desenlerin kendini tekrar etmeyen en küçük birimi altıgendir. Bundan dolayı bu desenler altıgen tabanlı olarak nitelendirilmiştir. Bu altıgen ızgara istenilen ebatlarda çoğaltılarak desen de istenilen miktarda çoğaltılabilir, hatta bu şekilde sonsuza kadar gidebilir. Biz bu desendeki altıgeni yedi adet olarak çoğalttık ve ortada yer alan altıgenin altı kenarına ayna simetrisi ile yerleştirerek deseni oluşturduk. Ayrıca bu yöntem sayesinde desen istenildiği kadar büyütülebilir. Izgaranın ebatları ne kadar büyütülürse desenin boyutu da o kadar büyümektedir. Bu da desenlerin istenilen ebatta kolayca çizilebilmesini sağlayacaktır (Çizim 9 ve Çizim 10).

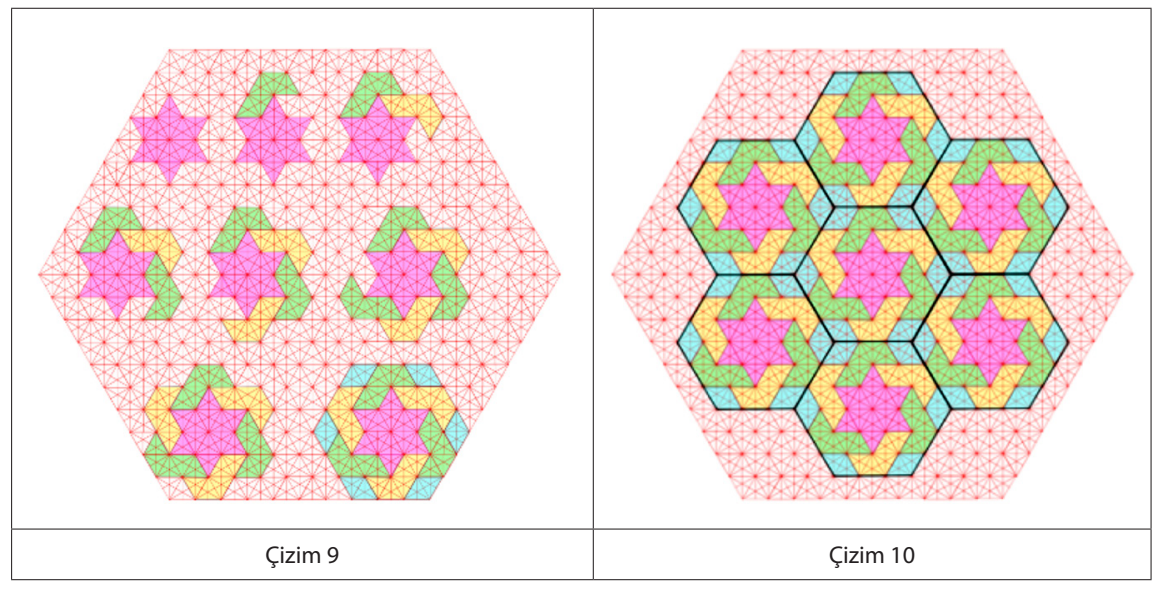

\section{Altıgen Tabanlı Geometrik Desenlerin Izgara Üzerinde Şematik Gösterimi}

İslam eserlerinde kullanılan geometrik desenleri basit bir gözle incelediğimizde bile desenlerin birbirlerine olan benzerliklerini, basit ve karmaşık olanlarını ayırt edebiliriz. Tarihsel sürece baktığımızda da geometrik desenlerin, matematiksel gelişme ile bağlantılı olarak gittikçe daha karmaşık bir hal aldığını tespit edebiliriz. Bu durumda geometrik desenleri incelemeye en basit olanlardan başlamak gerekmektedir. 
Aşağıdaki çizimlerde, çeşitli kaynak kitaplardan ve internet sayfalarından elde edilen verilerden hareketle Fas, Hindistan, İran, İspanya, Mısır, Özbekistan, Suriye, Türkiye ile İngiltere'deki bazı müze ve kütüphanelerde tespit edilen toplam 223 eserdeki 39 farklı geometrik desen, 13 grup halinde incelenmiştir. Bu desenler VIII.-XVIII. yüzyıllar arasında, Fatımi, Selçuklu, Mengücek, Eyyübi, Muvahhidler, İlhanlı, Khalji, Karamanoğulları, Memlük, Osmanlı, Timurlu, Akkoyunlu, Babür, Şeybani, Rajput, Safevi, Alevi, Tolunoğulları ve Emevi dönemi eserlerinde yer almaktadır. Bu çizimlerde farklı coğrafyalarda, apayrı eserlerde ve bambaşka tarihlerde yapılmış altıgen tabanlı 39 farklı desenin yeni ızgaraya tam olarak nasıl yerleştiğini görebiliriz. Daha anlaşılır olması için desenlerde yer alan farklı şekiller farklı renklerde gösterilmiştir. Desenler hakkında detaylı bilgiler EK 1, EK 2 ve EK 3'te yer almaktadır.

\subsection{Birinci Grup}

Bu grupta altıgen şekil kullanılarak oluşturulan desenler yer almaktır

\subsubsection{1a Grubu}

Bu desen sadece altıgen şekil kullanılarak oluşturulmuştur. Altıgenler altı yönde ayna simetrisi ile birleştirilmiştir.

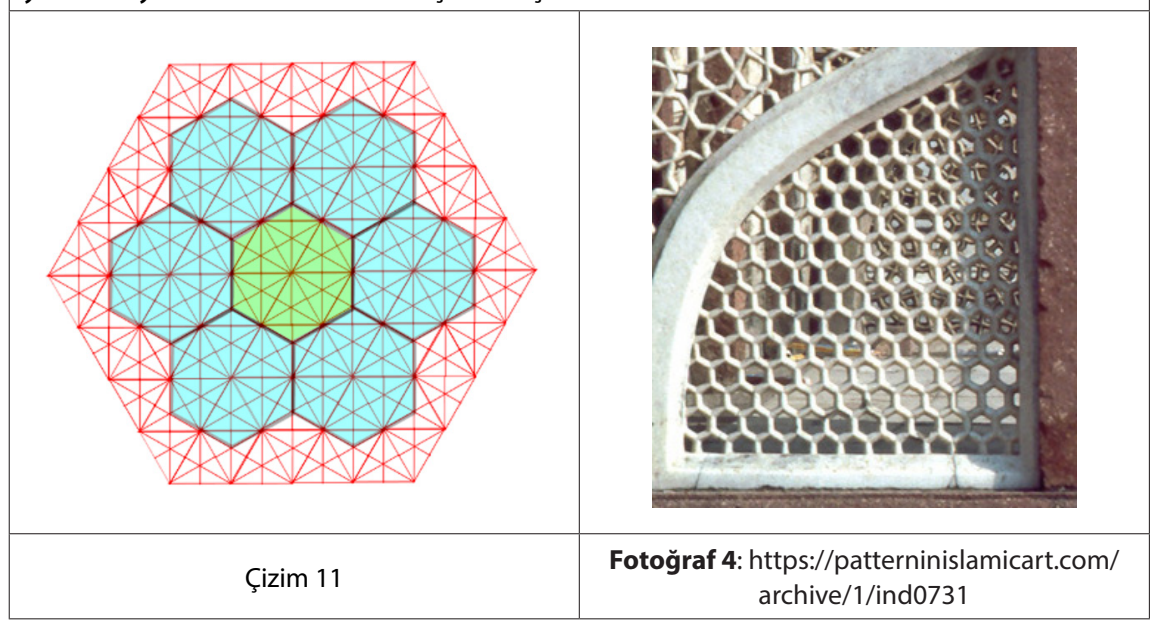




\subsubsection{1b Grubu}

Bu desen altıgen şekil ile altıgen şekillerin aralarına daha küçük altıgenlerin yerleştirilmesi ve ayna simetrisi ile birleştirilmesiyle oluşturulmuştur.

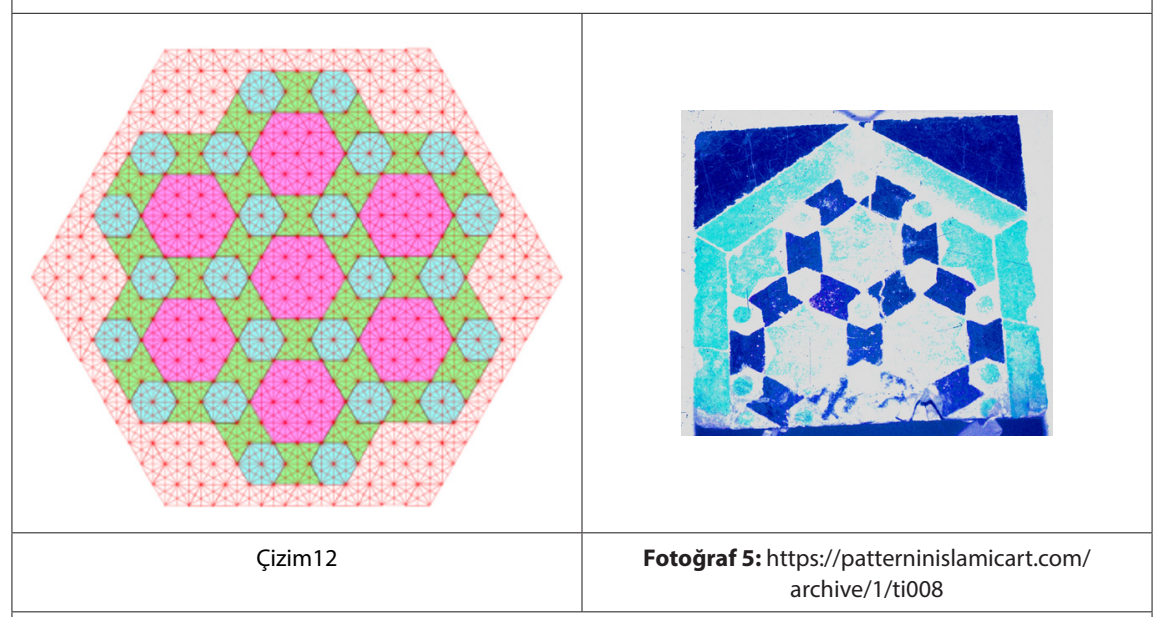

\section{2 İkinci Grup}

Bu grupta altıgen ve üçgen şekillerinin bir arada kullanılmasıyla oluşturulan desenler yer almaktadır.

\subsubsection{2a Grubu}

Bu desen, bir altıgen ile altıgenin bir kenar uzunluğuna eşit uzunlukta altı adet eşkenar üçgenin birleşmesi ve ayna simetrisi ile çoğaltılmasıyla oluşturulmuştur.

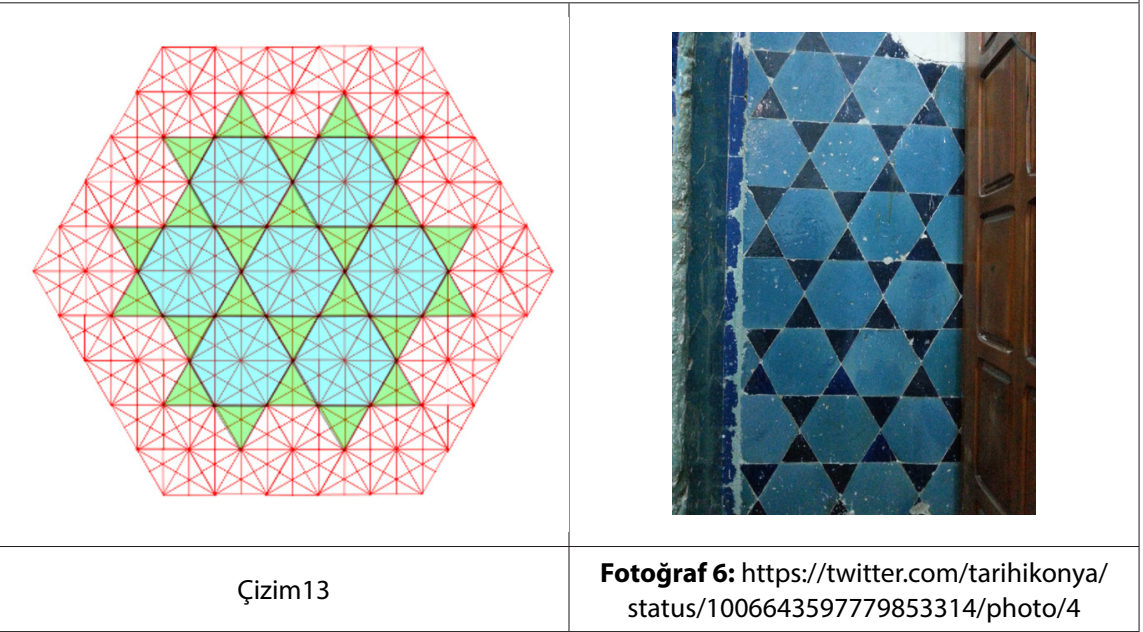




\subsubsection{2b Grubu}

Bu desen, bir altıgen ve onun etrafına ayna simetrisi ile gelen, altıgenin kenar uzunluğunun iki katı uzunlukta altı adet eşkenar üçgenin birleştirilmesiyle oluşturulmuştur.

\begin{tabular}{|c|c|}
\hline Çizim 14 & Fotoğraf 7: http://blog.istanbul1881.com/fatih- \\
sultan-mehmet-ve-topkapi-sarayi/cinili-kosk-10/
\end{tabular}

\subsubsection{2c Grubu}

Bu desen bir altıgen ve onun etrafına ayna simetrisi ile gelen, altıgenin kenar uzunluğunun yarısı uzunlukta 24 adet eşkenar üçgenin birleştirilmesiyle oluşturulmuştur.

Çizim15




\section{3 Üçüncü Grup}

Bu grupta altıgen ve yıldız şekillerinden oluşan desenler yer almaktadır.

\subsubsection{3a Grubu}

Bu desen bir adet altı köşeli yıldız ve onun etrafına ayna simetrisi ile yerleştirilmiş altı adet altıgen şeklin birleştirilmesiyle oluşturulmuştur.

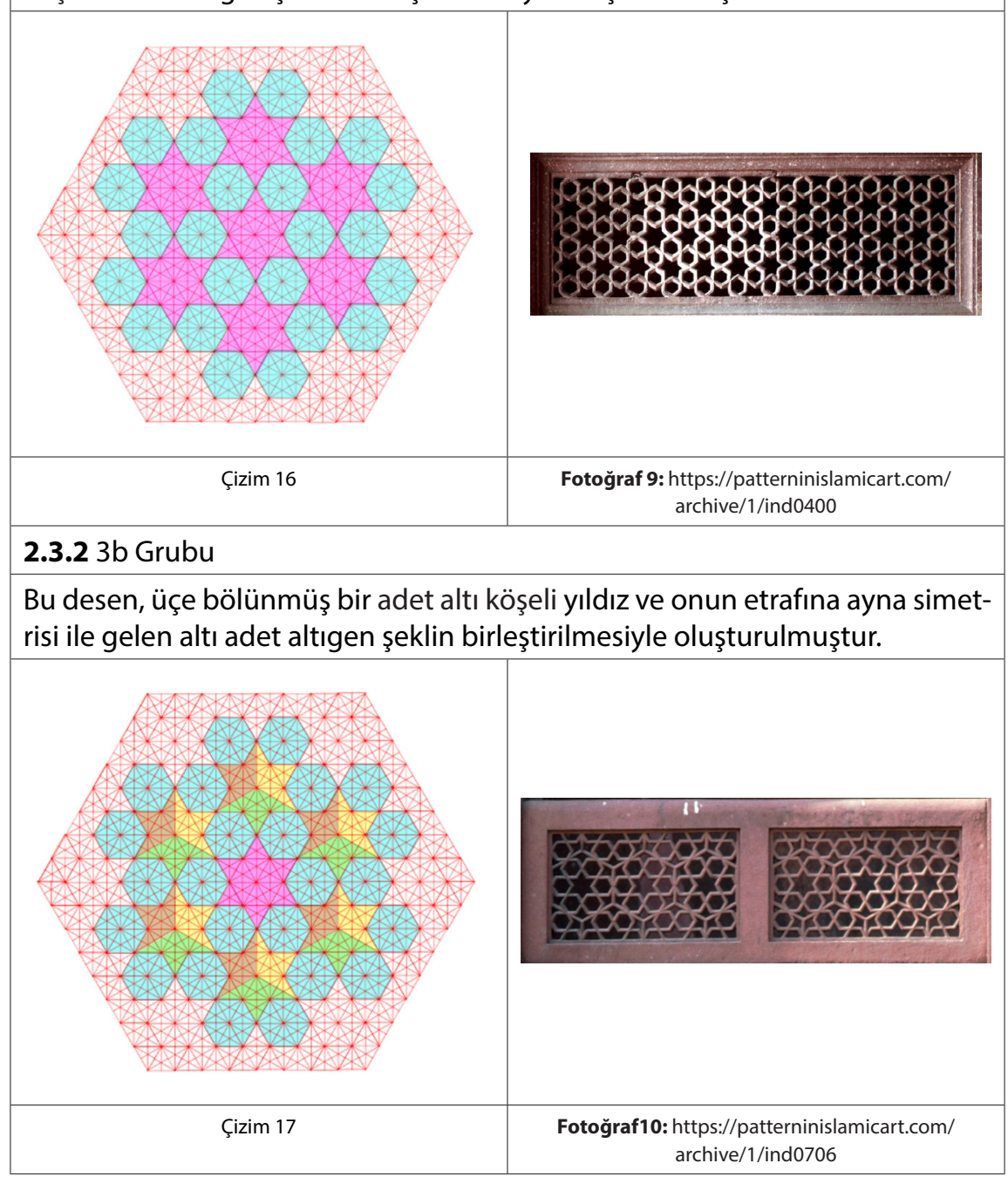




\subsubsection{3c Grubu}

Bu desen, altıya bölünmüş bir adet altı köşeli yıldız ve onun etrafına ayna simetrisi ile yerleştirilen altı adet altıgen şeklin birleştirilmesiyle oluşturulmuştur.

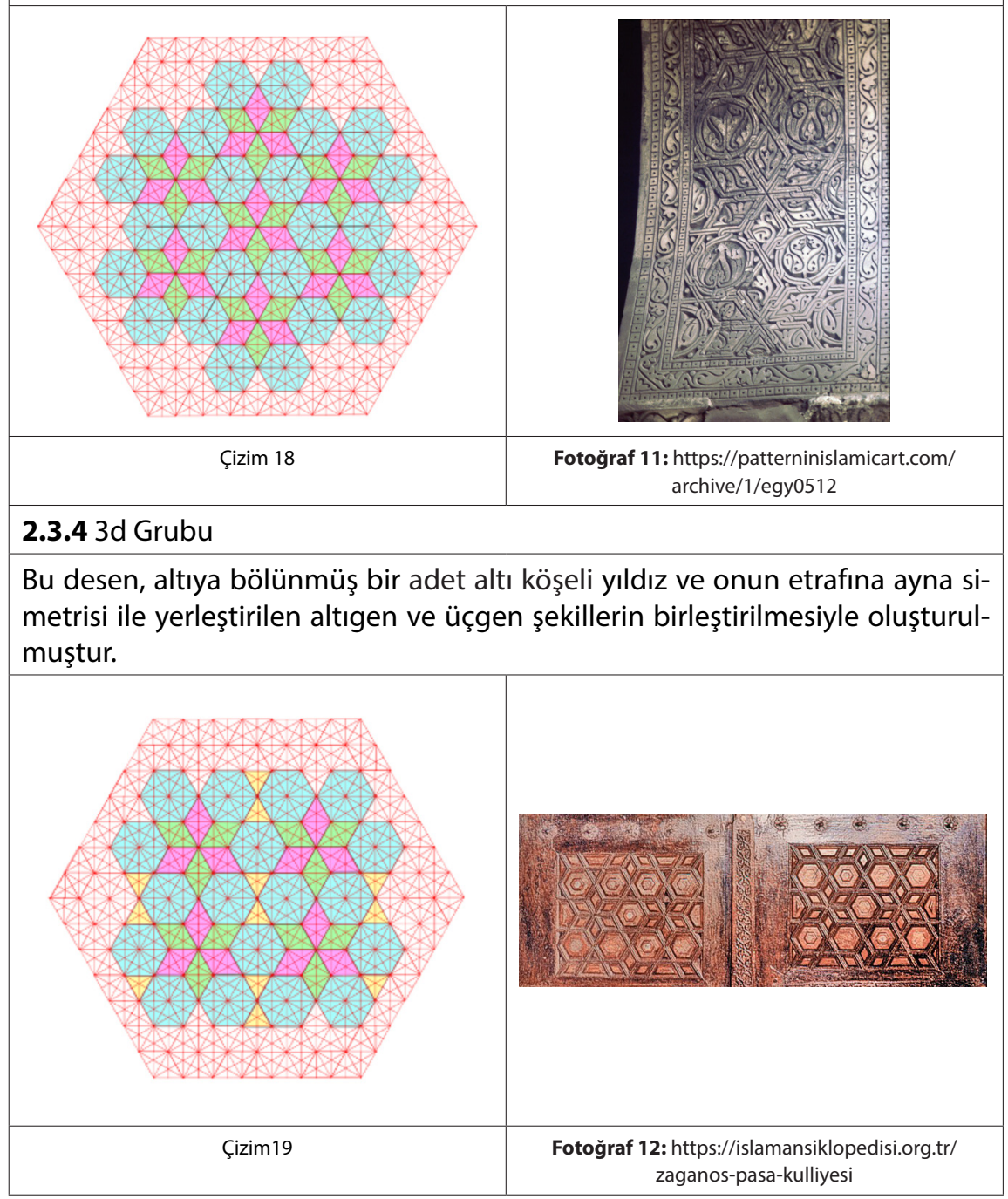




\subsubsection{3e Grubu}

Bu desen bir adet altı köşeli yıldız, onun etrafına ayna simetrisi ile yerleştirilmiş altı adet altıgen ve onların da etrafını saran geometrik şekillerden oluşturulmuştur.

\begin{tabular}{|c|c|}
\hline & \\
\hline & \\
\hline
\end{tabular}

Bu grupta altı yönde birbirinin etrafını fırıldak gibi saran geometrik şekillerden oluşan desenler yer almaktadır.

\subsubsection{4a Grubu}

Bu desen, merkezde yer alan altıgen ile altıgenin etrafını altı yönde fırıldak şeklinde saran "Z" biçimli şekillerin birleştirilmesiyle oluşturulmuştur.

\begin{tabular}{|c|}
\hline \\
\hline Çizim 21
\end{tabular}




\subsubsection{4b Grubu}

Bu desen ortada yer alan altı köşeli yıldız ile yıldızın etrafını fırıldak gibi saran geometrik şekillerin birleştirilmesiyle oluşturulmuştur.

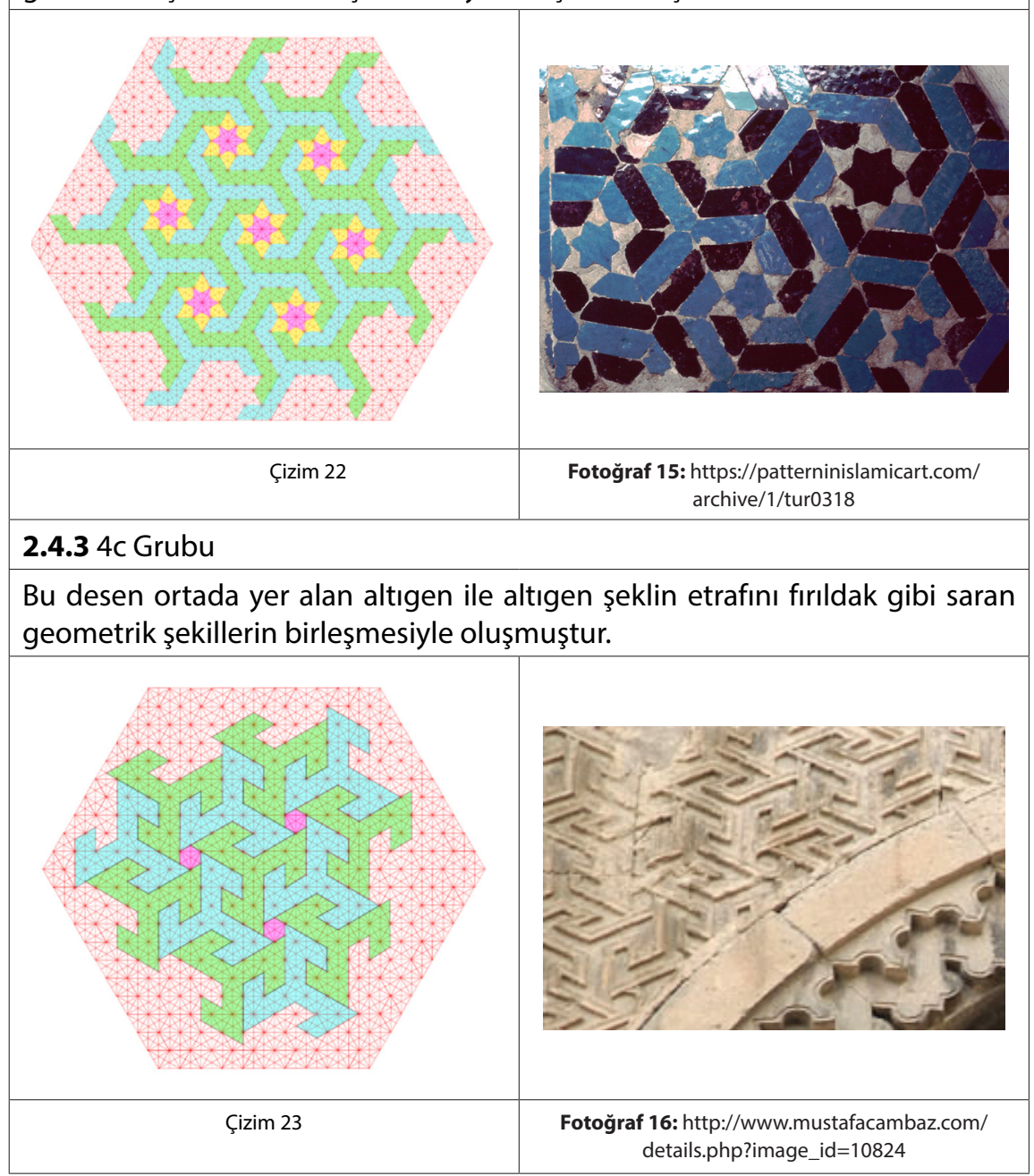




\subsection{Beşinci Grup}

Bu grupta altıgen ve yıldızlar şekilleri ile bu şekillerin etrafını dönerek saran geometrik şekillerle oluşan desenler yer almaktadır.

\subsubsection{5a Grubu}

Bu desen bir adet altıgen ile altıgenin etrafını dönerek saran altı adet paralelkenar şeklin birleştirilmesiyle oluşturulmuştur.

\begin{tabular}{|l|l|}
\hline Çizim 24 & F̧izim 25 \\
B.5.2 5b Grubu desen bir adet altı köşeli yıldız ile onun etrafını dönerek saran altı adet pa- \\
ralelkenar ve üçgen şekillerin birleştirilmesiyle oluşturulmuştur. \\
\hline
\end{tabular}




\subsubsection{5c Grubu}

Bu desen, ortada bir adet altı köşeli yıldız ile altıgenle birlikte yıldızın etrafını saran geometrik şekillerin birleştirilmesiyle oluşturulmuştur.

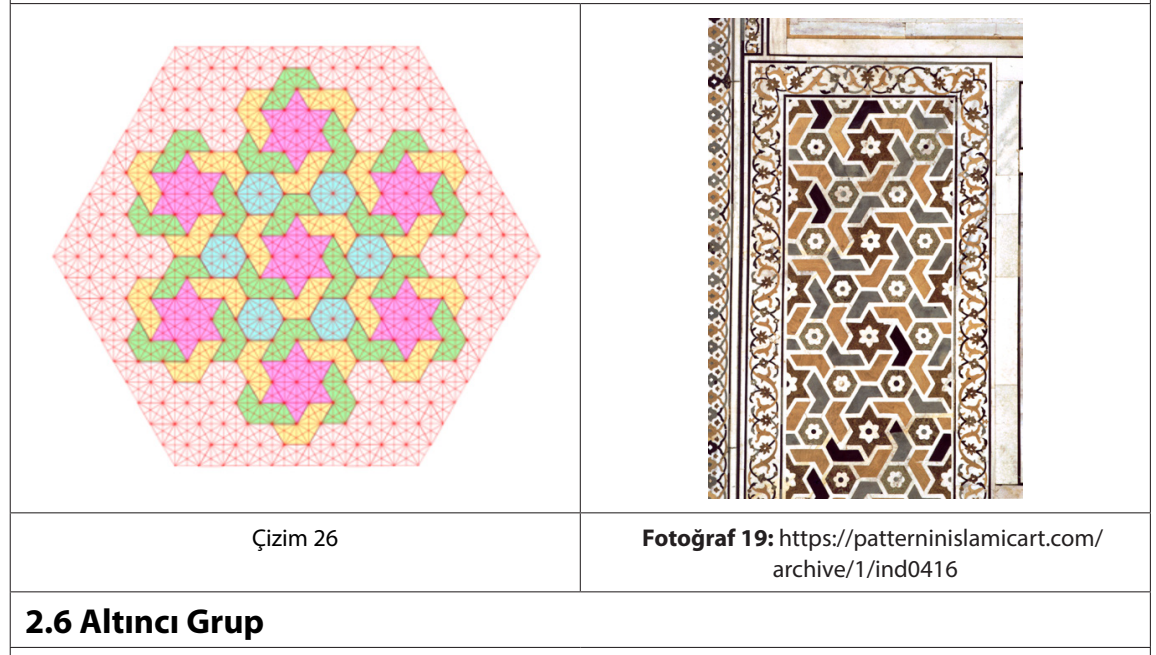

Bu grupta, ortadaki altı köşeli yıldız ile yıldızın etrafını saran çubuk şekilleriyle meydana gelen altıgenlerin birleşmesiyle oluşmuş desenler yer almaktadır.

\subsubsection{6a Grubu}

Bu desen, ortadaki altı köşeli yıldız ile yıldızın etrafını saran çubuk şekillerin birleşmesiyle oluşan altıgenlerden meydana gelmiştir.

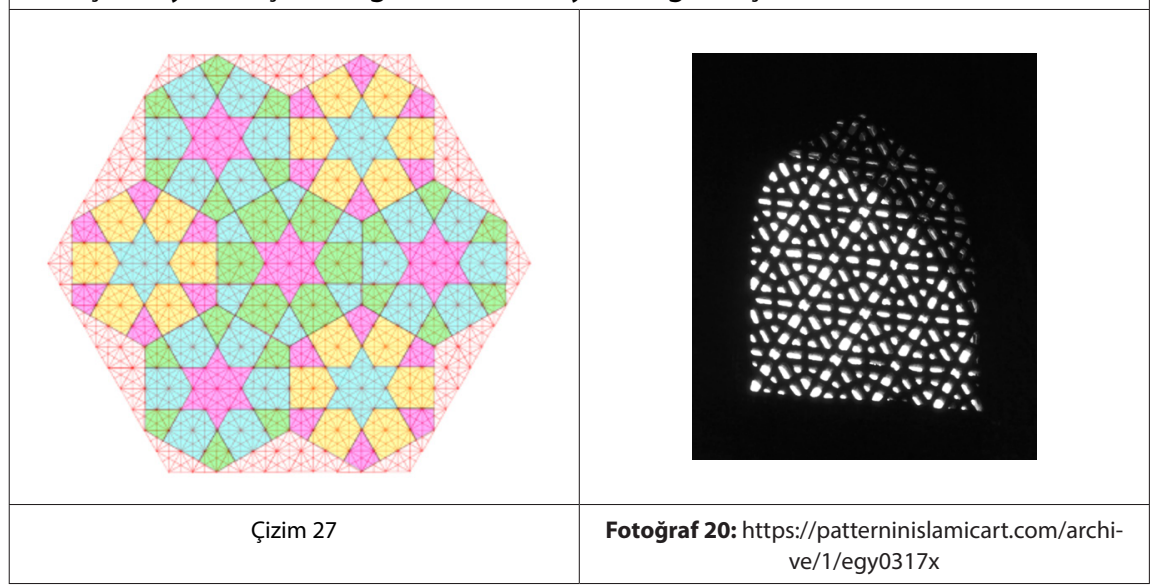




\subsubsection{6b Grubu}

Bu desen, ortadaki altı köşeli yıldız ile yıldızın çevresini saran çubuk şekillerinden oluşan altıgenlerin çevrelerindeki diğer geometrik şekillerle birleştirilmesiyle oluşturulmuştur.

\begin{tabular}{|l|l|}
\hline & \\
\hline 2̧izim 28 & Fotoğraf 21: https://patterninislamicart.com/ \\
\hline Bu desen, ortadaki altı köşeli yıldı ile yıldızın etrafını saran çubuk şekilleri ile \\
oluşan altıgenlerin, altıgen aralarında bulunan diğer geometrik şekillerle bir- \\
leştirilmesiyle oluşturulmuştur.
\end{tabular}




\subsubsection{6d Grubu}

Bu desen, ortada yer alan altı köşeli yıldız ile yıldızın etrafını saran çubuk şekilleri ile oluşan altıgenlerin, altıgen aralarındaki diğer şekillerle birleştirilmesiyle oluşturulmuştur.

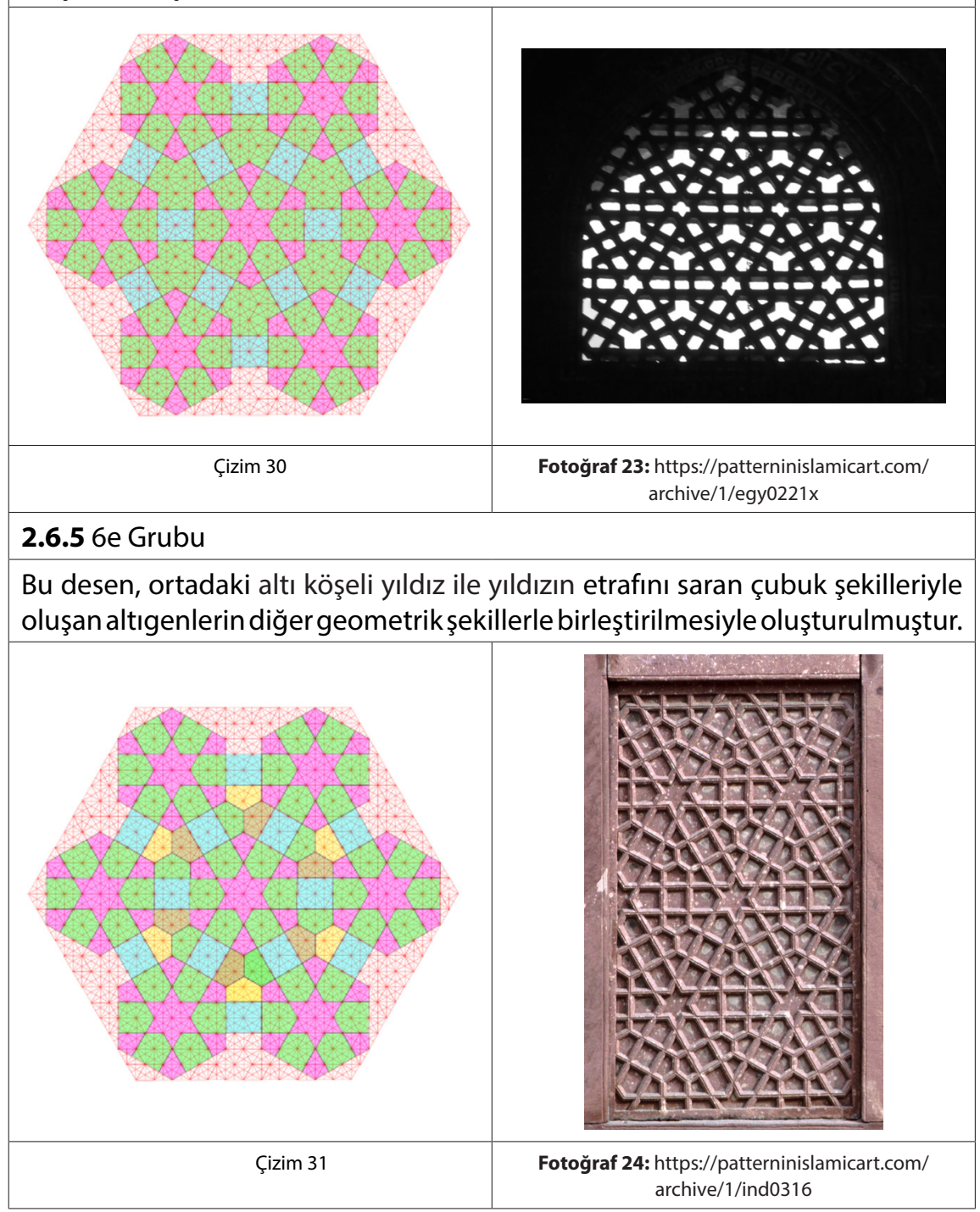




\subsection{6 $6 f$ Grubu}

Bu desen, ortada yer alan üçe bölünmüş altı köşeli yıldız ile yıldızın etrafını saran çubuk şekilleriyle oluşan altıgenlerin, altıgen aralarındaki diğer geometrik şekillerle birleştirilmesiyle oluşturulmuştur.

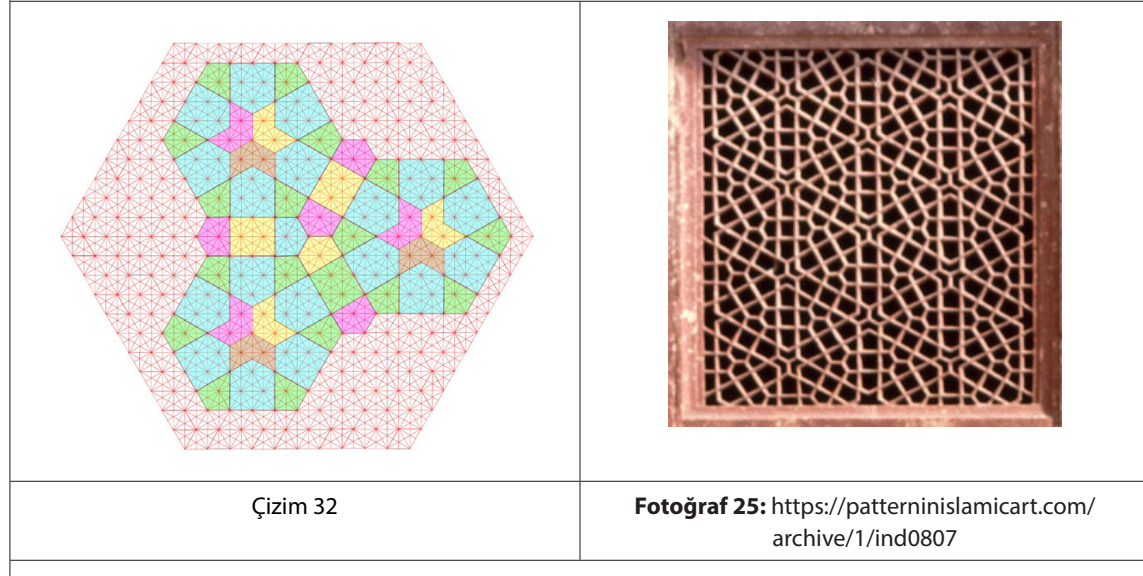

\subsection{Yedinci Grup}

Bu grupta altı köşeli yıldız ile yıldız şeklin etrafını saran çubuk şekilleriyle oluşan altıgenlerin, altıgen aralarında yer alan yıldız şekilleriyle birleştirilmet sinden oluşan desenler yer almaktadır.

\subsubsection{7a Grubu}

Bu desen, merkezde yer alan altı köşeli yıldız şekli ile yıldızın etrafını saran çubuk şekilleriyle oluşan altıgenlerin, daha küçük altıgenler ve merkezdeki yıldızdan farklı yöne döndürülmüş altı köşeli yıldız şekliyle birleştirilmesiyle oluşturulmuştur.

\begin{tabular}{|c|c|}
\hline & \\
\hline &
\end{tabular}




\subsubsection{7b Grubu}

Bu desen, ortada yer alan altı köşeli yıldız şekli ile yıldız şeklin etrafını saran çubuk şekillerinin birleştirilmesiyle oluşturulmuştur.

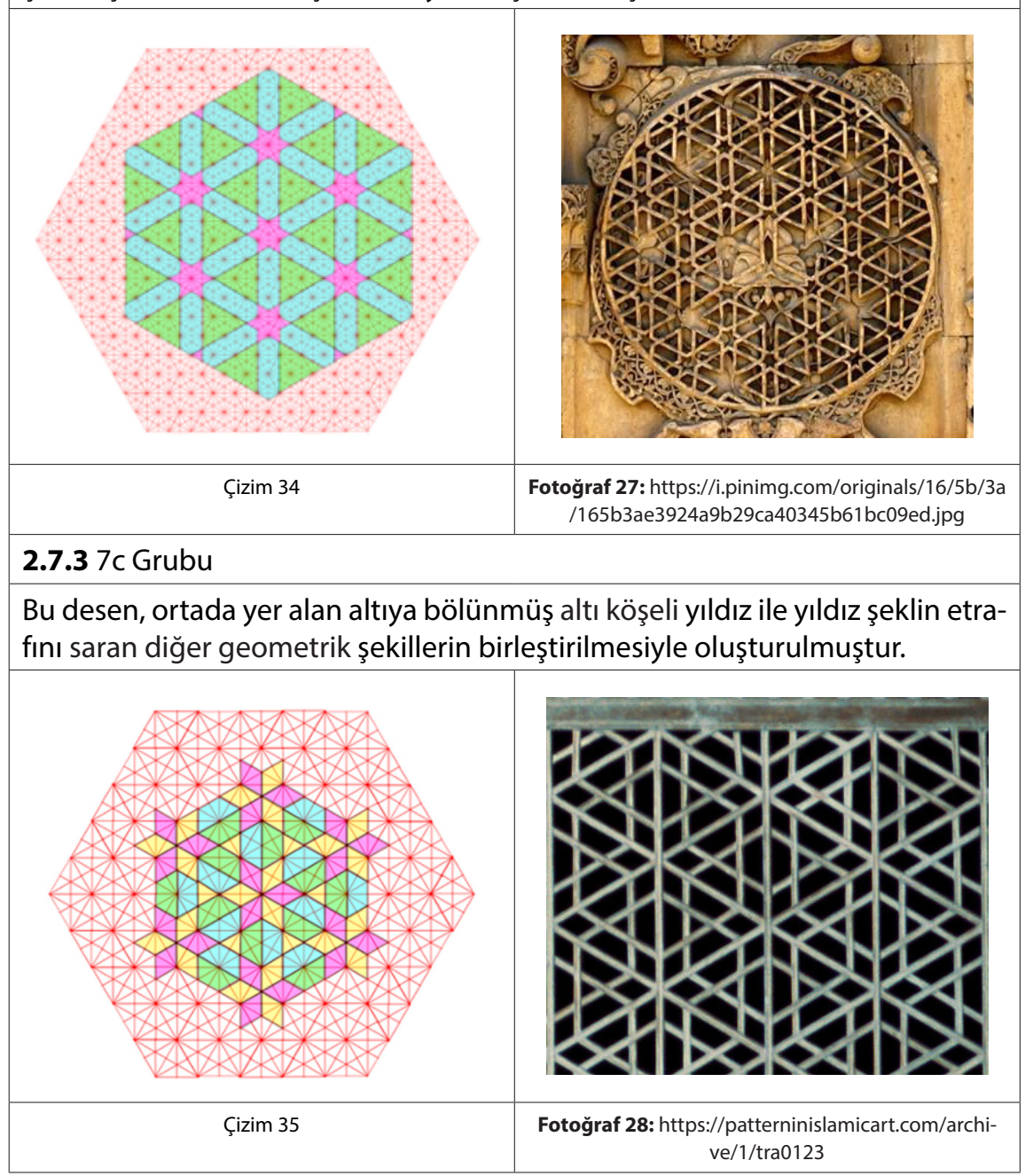




\subsection{Sekizinci Grup}

Bu grupta altı köşeli yıldız ile yıldız şeklin etrafını saran " $T$ " biçimindeki şekillera in birleşmesiyle oluşmuş desenler yer almaktadır.

\subsubsection{8a Grubu}

Bu desen bir adet altı köşeli yıldız ile yıldız şeklin etrafını saran " $T$ " biçimli şekiller ile diğer geometrik şekillerin birleştirilmesiyle oluşturulmuştur.

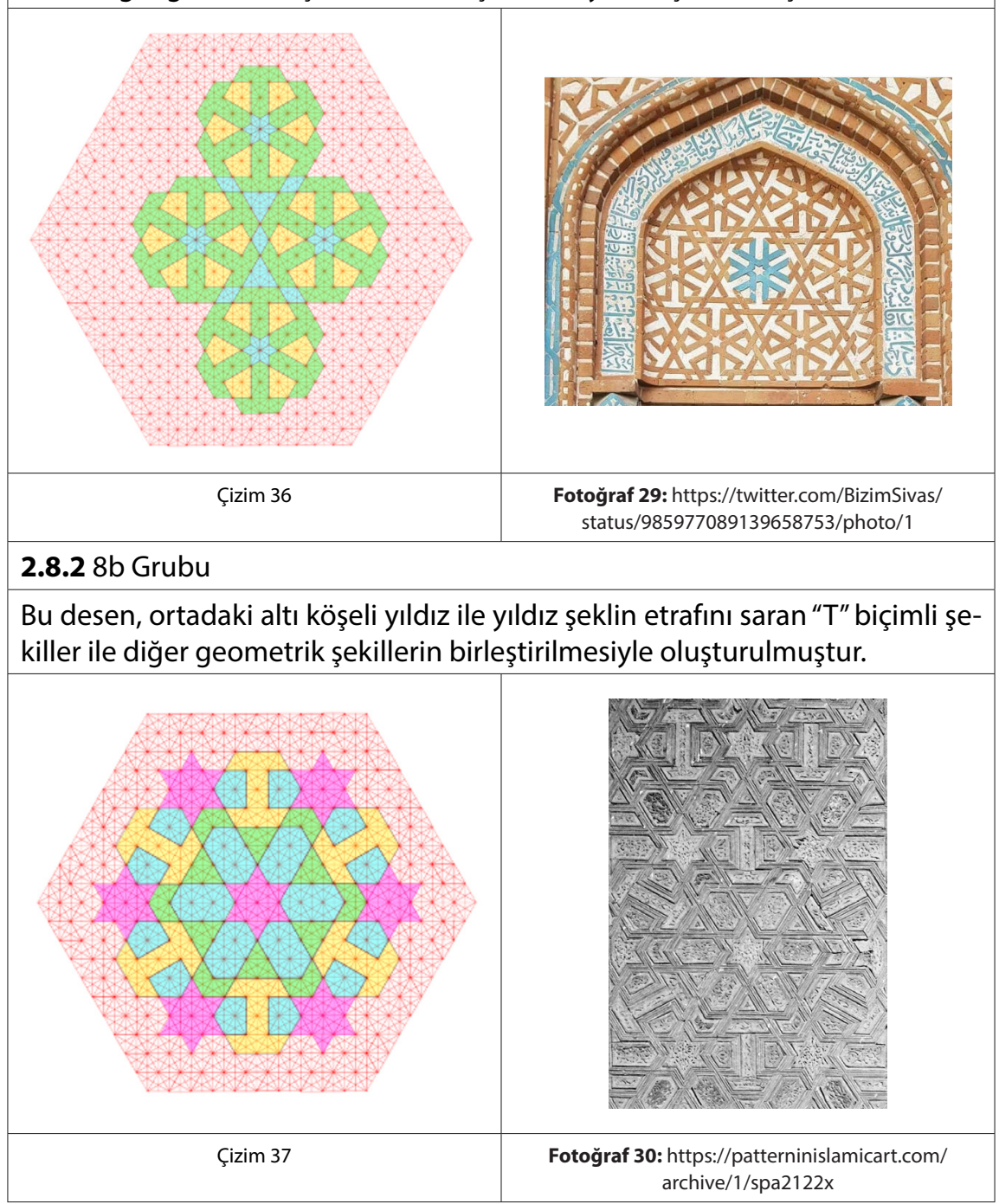




\subsection{Dokuzuncu Grup}

Bu grupta, altı köşeli yıldız ile yıldız şeklin etrafını saran altıgen ve deltoid (kez lebek) şekilerin birleşmesiyle oluşan desenler yer almaktadır.

\subsubsection{9a Grubu}

Bu desen, ortada yer alan altı köşeli yıldız ile onun etrafını saran altıgen ve deltoid (kelebek) şeklin birleştirilmesiyle oluşturulmuştur.

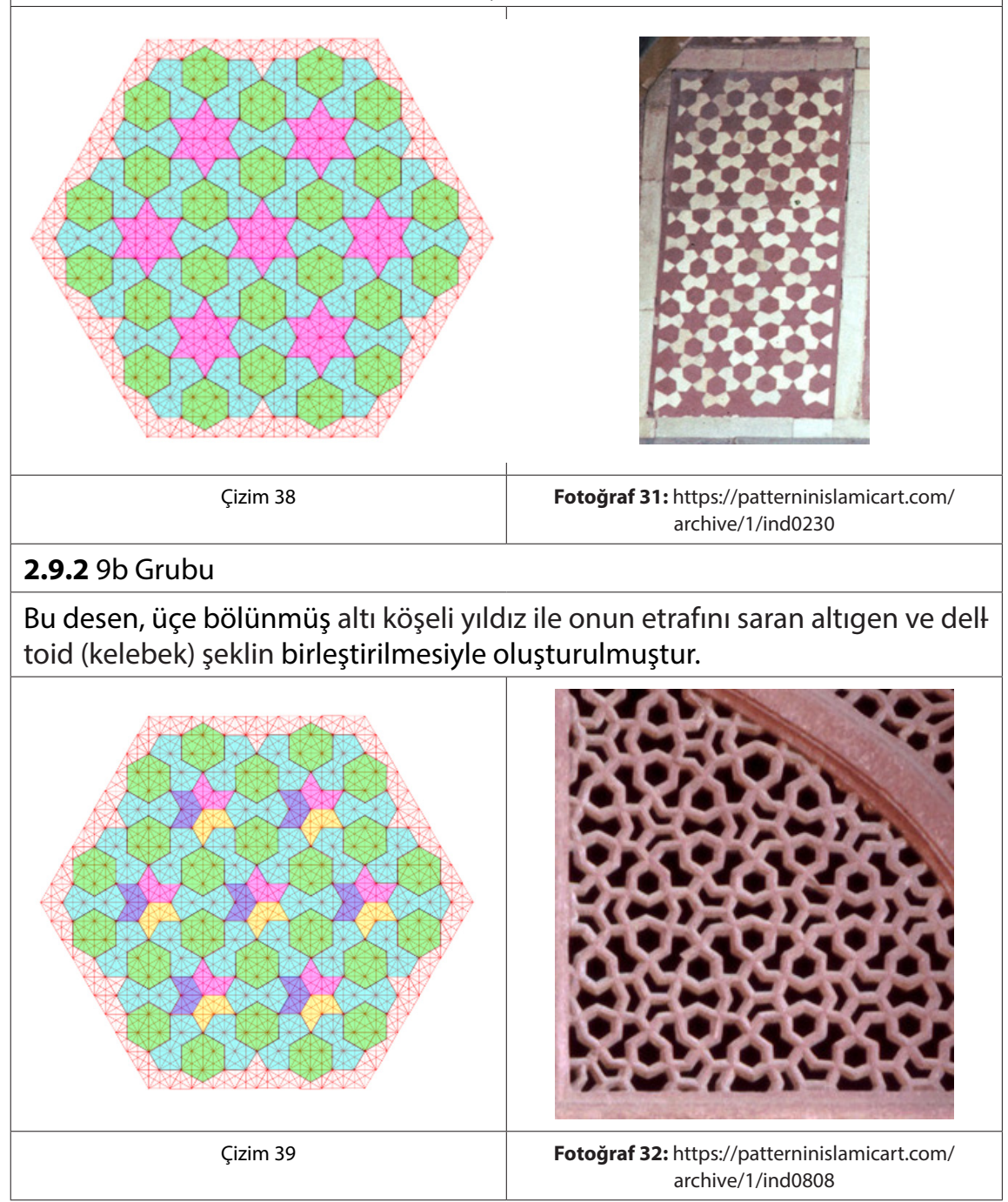




\section{MÎZÂNÜ'L-HAK}

\subsection{Onuncu Grup}

Bu grupta altı köşeli yıldız ile yıldız şeklin etrafını dönerek saran geometrik şekillerin birleşmesiyle oluşan desenler yer almaktadır.

\subsubsection{0a Grubu}

Bu desen, altı köşeli yıldız ile yıldız şeklin etrafını dönerek saran ok ucu ve altıgen şekillerin birleşmesiyle oluşmuştur.

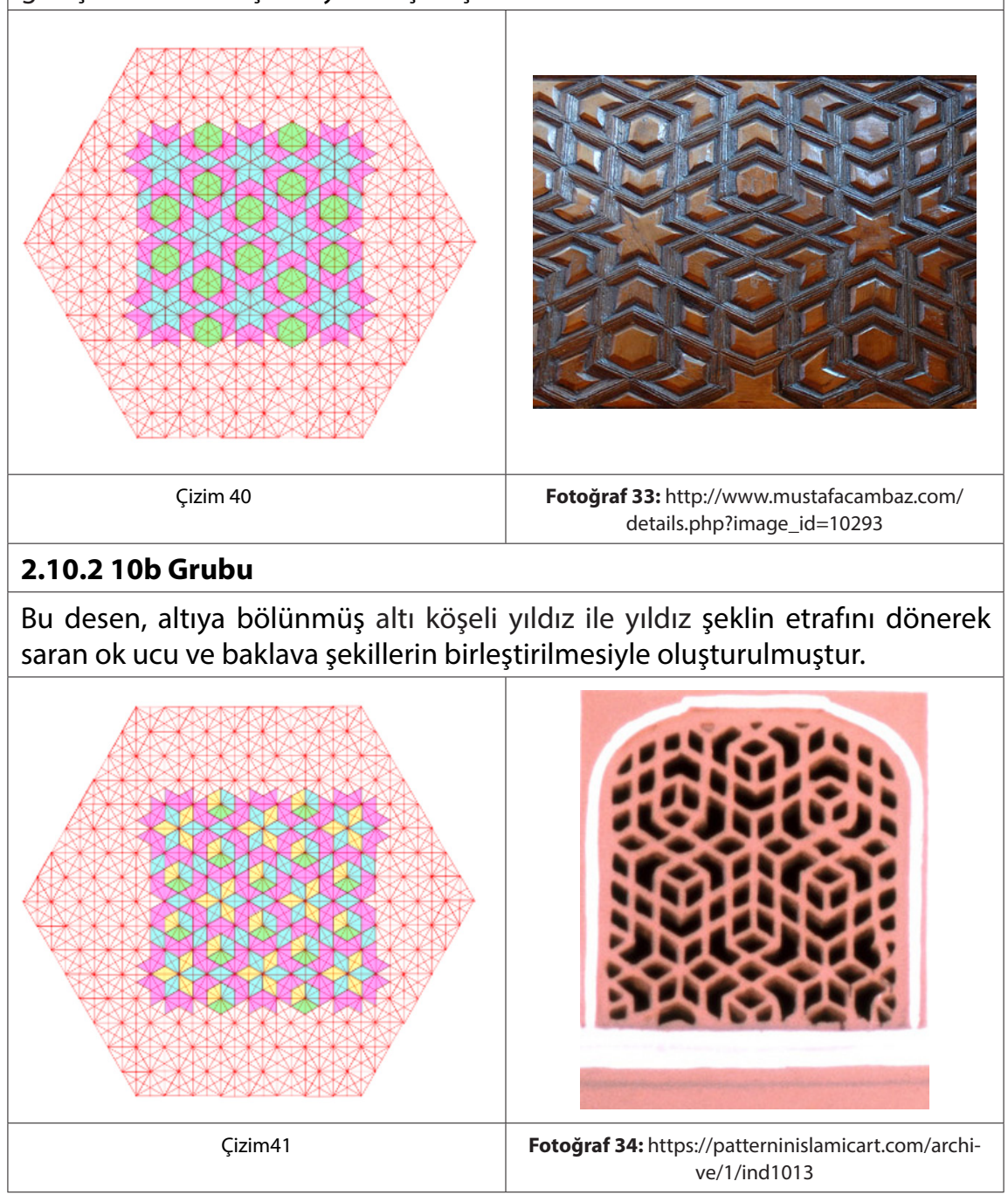




\subsection{On Birinci Grup}

Bu grupta altı köşeli yıldız ile yıldız şeklin etrafını saran altıgen ve diğer geod metrik şekillerle oluşan desenler yer almaktadır.

\section{1a Grubu 2.11.1}

Bu desen, altı köşeli yıldız ile yıldız şeklin etrafını saran altıgen, baklava ve diğer geometrik şekillerin birleştirilmesiyle oluşturulmuştur.

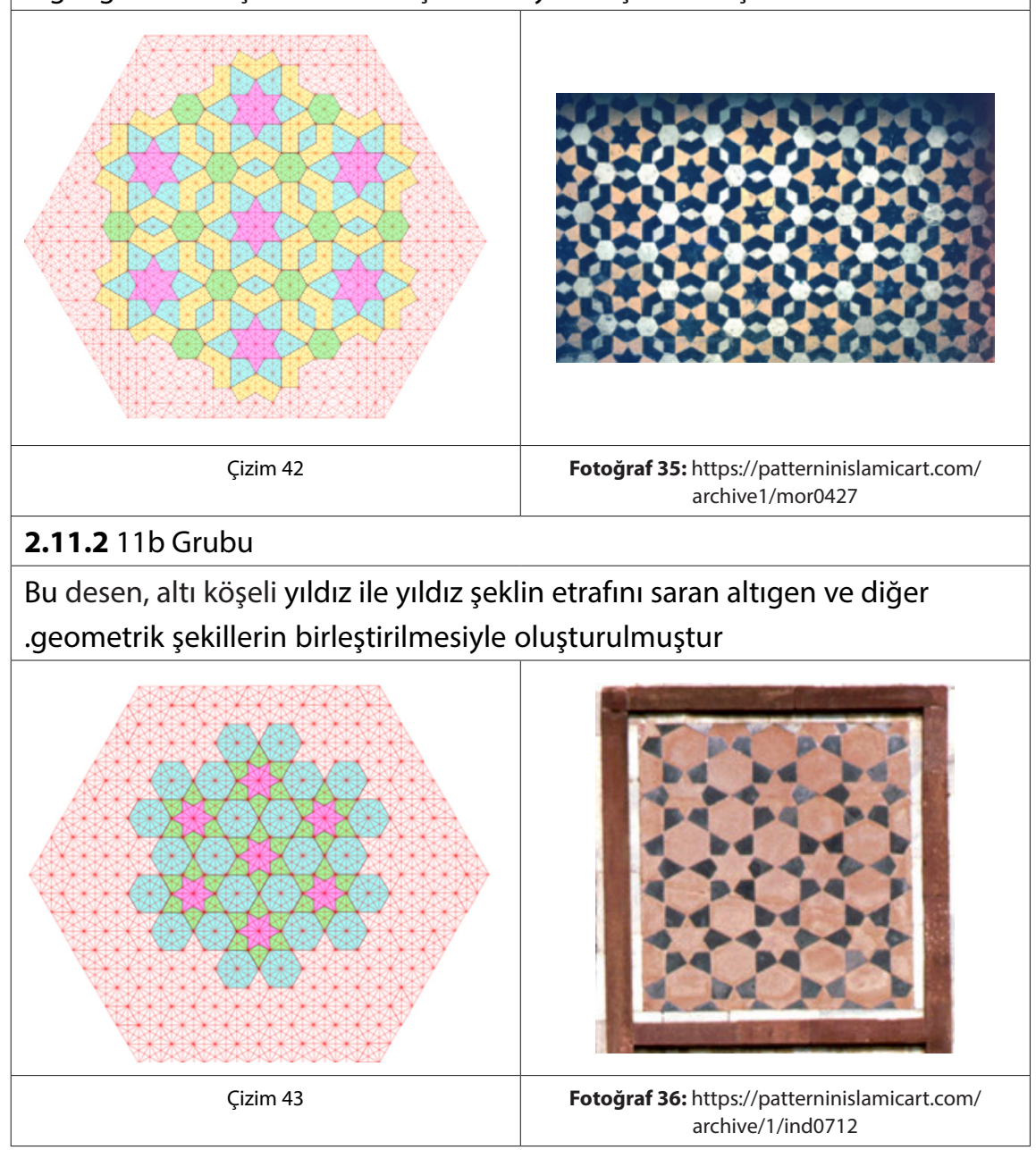




\section{MÎZÂNÜ'L-HAK}

\subsection{On İkinci Grup}

Bu grupta altı köşeli yıldız ve baklava şekilleri kullanılarak oluşturulan desenler yer almaktadır.

\subsubsection{2a Grubu}

Bu desen sadece baklava şekli kullanılarak oluşturulmuştur.

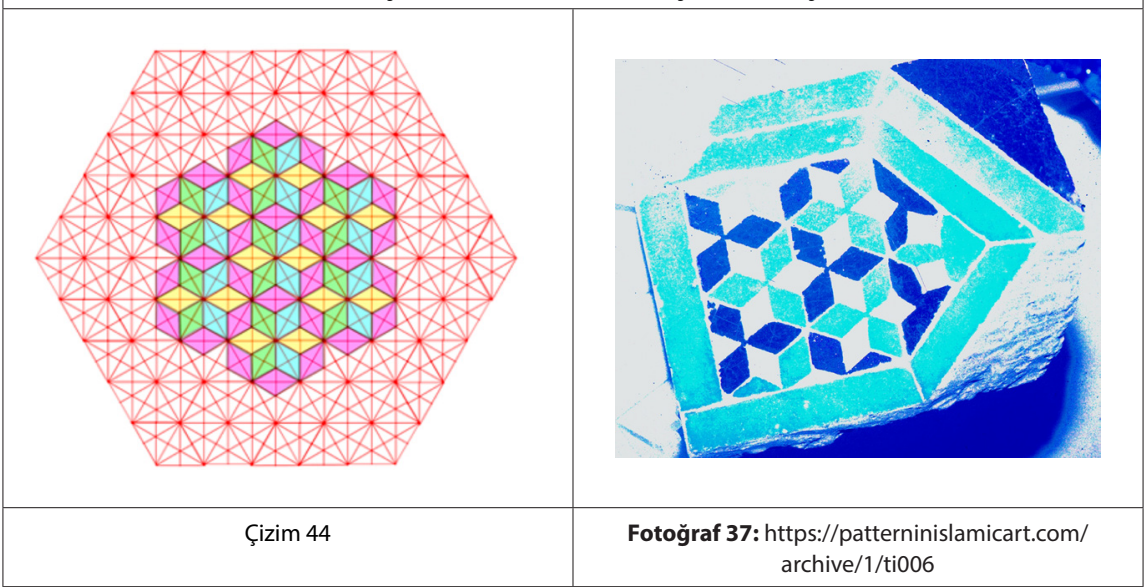

\subsubsection{2b Grubu}

Bu desen altı köşeli yıldız ve baklava şekli kullanılarak oluşturulmuştur.

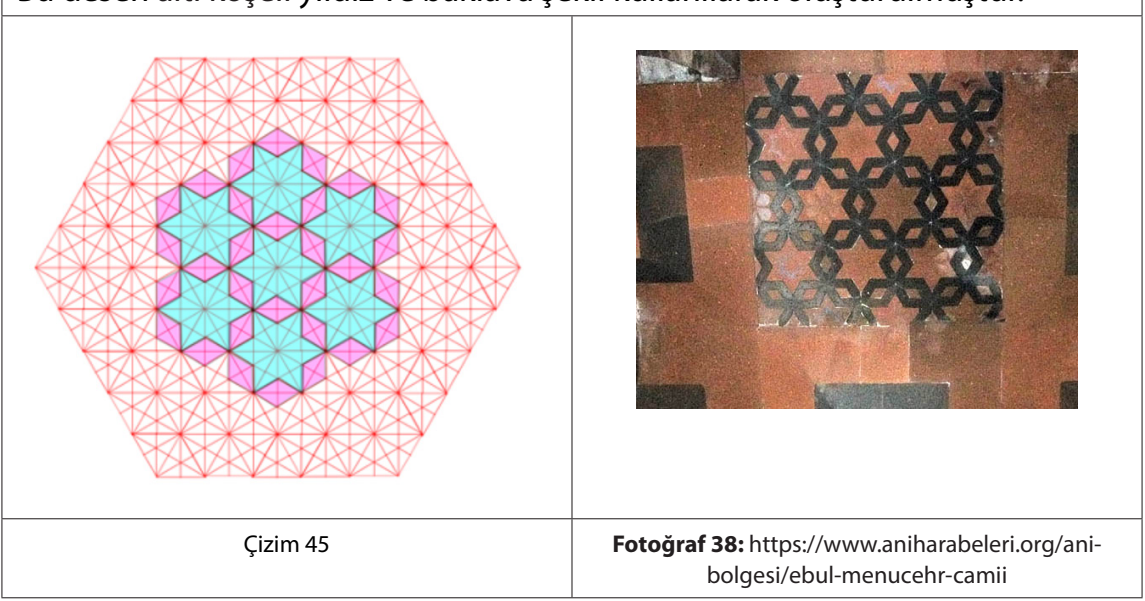




\subsection{On Üçüncü Grup}

Bu grupta uçurtma şekli kullanılarak oluşan desenler yer almaktadır.

\subsubsection{3a Grubu}

Bu desen sadece uçurtma şekli kullanılarak oluşturulmuştur.

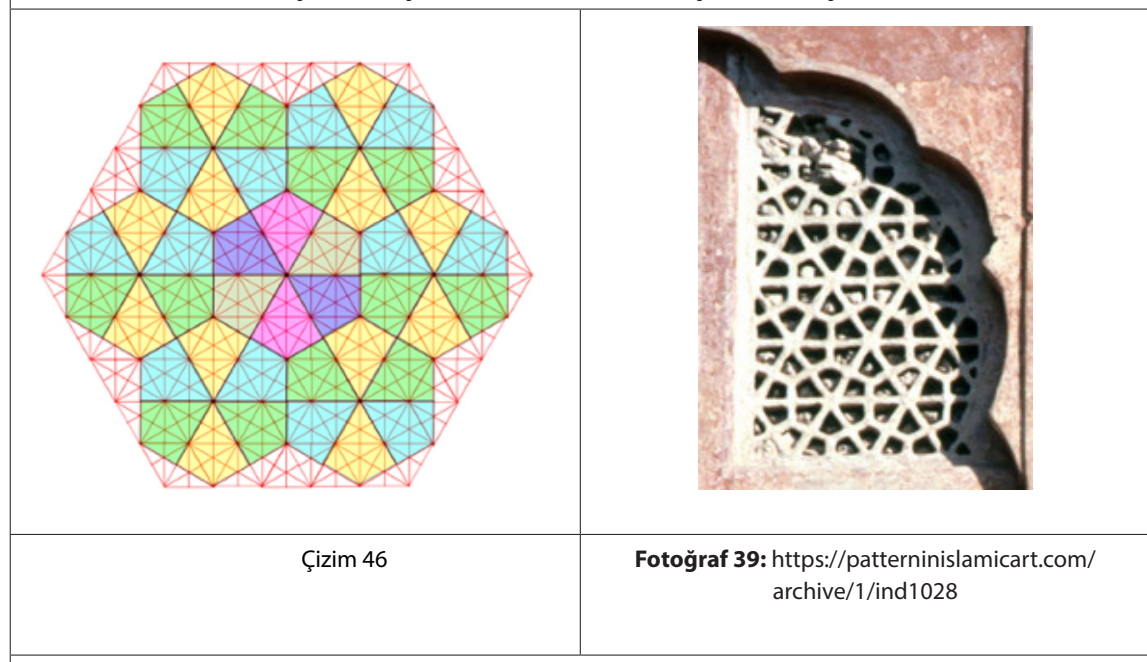

\subsubsection{3b Grubu}

Bu desen uçurtma ve üçgen şekli kullanılarak oluşturulmuştur.

\begin{tabular}{|c|c|}
\hline & \\
\hline &
\end{tabular}




\subsubsection{3c Grubu}

Bu desen uçurtma şekli ve onun etrafını saran deltoid (kelebek) şekiller kule lanılarak oluşturulmuştur.

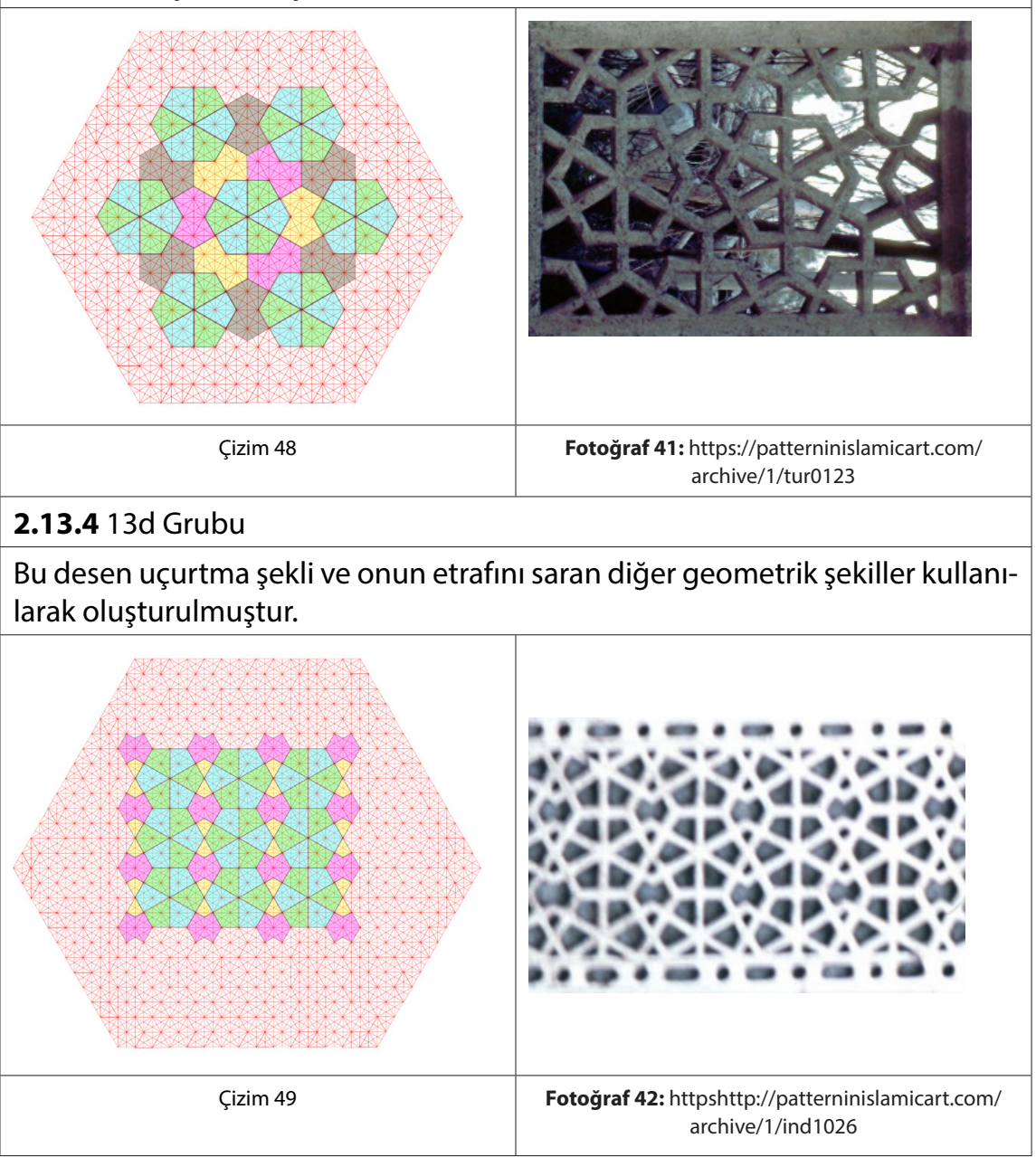

\section{Değerlendirme ve Sonuç}

Evrenin yasaları sonsuz, zorunlu ve değişmez yasalardır. Evrenin matematik sistemi de birçok anlam yüklü geometrik şekillerle yansımaktadır. Geometrik sistemlerdeki ritmik düzen ve ahenk evrensel düzenin de ahengini ifade etmektedir. Geometrik kompozisyonlar sonsuzluk ifadesine sahiptirler. Buna en güzel 
örnek yıldız sistemleridir. ${ }^{40}$ İslam eserlerinde kullanılan geometrik desenler de matematik bilimi ile doğrudan bağlantılıdır. Hatta tarihsel dönemleri incelediğimizde matematik biliminin gelişmesi ile birlikte kullanılan geometrik desenlerin de bu gelişmeyle paralel olarak daha karmaşık bir hal aldığını görüyoruz. Bu çalışmamızda nispeten daha basit olarak görülen ve altıgen tabanlı olarak niteleyebileceğimiz bazı geometrik desenleri incelemeye çalıştık. Bu desenlerin bölgelere, kullanılan malzemeye ve tarihsel sürece göre analizlerini yaptık.

Altıgen tabanlı geometrik desenler 80 adet ile en çok Türkiye'de görülmüştür. Bunu 66 adet ile Hindistan, 22 adet ile Mısır, 13 adet ile Özbekistan, 12 adet ile İngiltere'deki müzeler, 11 adet ile İran, 9 adet ile Suriye, 4 er adet ile Fas ve İspanya takip etmiştir (EK 1).

Altıgen tabanlı geometrik desenlerin en çok taş malzemeye uygulandığı tespit edilmiştir (79 adet). Ayrıca mozaik çini (39 adet), ahşap (26 adet) sıva ve renkli taş mozaik (23'er adet), taş mozaik ve dekoratif panel (12'şer adet), çini ve tuğla (4'er adet) ile kâğıt üzerine tezhip olarak (1 adet) uygulandığı da gözlemlenmiştir (EK 2).

Elimizdeki verilere göre altıgen tabanlı geometrik desenlerin 48 adet ile en çok XVI. yüzyılda uygulandığı görülmektedir. XIII. yüzyılda 34 adet, XVII. yüzyılda 31 adet, XV. yüzyılda 24 adet, XIV. yüzyılda 13 adet örnek görülmüştür. 12 adet XVIII. yüzyılda, 11 adet IX. yüzyılda, 9 adet XI. yüzyılda, 6 adet XII. yüzyılda, 4'er adet $X$. yüzyılda ve XIV-XV. yüzyılda, 3 adet VIII. yüzyılda ve 2 adet olmak üzere en az XIII-XV. yüzyılda altıgen tabanlı geometrik desenlere rastlanmıştır (EK 3).

Çalışmamızda ulaşabildiğimiz İslâm eserlerinin birbirinden farklı malzemelerle, değişik coğrafyalarda ve dönemlerde üretilmiş olmalarına rağmen eserlerde birebir aynı desenlerin kullanıldığı gözlemlenmiştir. Bu durum, bir şekilde elden ele ulaşan bir ızgara ya da şablonun varlığını kanıtlar niteliktedir. Çünkü bu desenlerin analizi veya tekrar tekrar çizilip çoğaltılabilmesi için kılavuz çizgilerine (kareleme ya da ona benzer çizgilere ) ihtiyaç vardır. ${ }^{41}$ Dolayısıyla bir ızgara yöntemi ile oluşturulmuş desenlerin gezici ustalar vasıtasıyla farklı coğrafyalarda uygulanmış olması kuvvetle muhtemeldir.42

40 Ögel, Anadolu Selçuklu Sanatı Üzerine Görüşler, 98.

41 Mülayim, Anadolu Türk Mimarisinde Geometrik Süslemeler, 70.

42 Doğan Kuban, Türk ve İslam Sanatı Üzerine Denemeler, (İstanbul: Arkeoloji ve Sanat Yayınları, 2015),36. 
Bazı araştırmacılar geometrik desenleri açıklarken daireden hareketle sonsuz geometrik şekillerin üretilebileceğini ifade etmişlerdir. ${ }^{43}$ Ancak desenlerin oluşturulması konusunda daire çizmek yerine burada ortaya koyduğumuz ızgaradan faydalanmak, desenlerin farklı ebatlarda, tekrar tekrar üretilmesinde pratik bir yöntem olarak görülmektedir. Özellikle ebatlar söz konusu olduğunda geometrik desenlerin (herhangi bir yüzeye uygulanması noktasında) daire çizerek oluşturulmaya çalışılması işlerin oldukça karmaşık bir hal almasına yol açmaktadır. Bu çalışmamızda yer verdiğimiz 223 adet eserde yer alan 39 farklı desenin oluşturduğumuz yeni ızgara sistemine birebir uyduğu görülmektedir. Ayrıca farklı yöntemlerle çizilen bir desenin oluşturduğumuz yeni ızgara ile kolayca nasıl elde edilebildiği de açıklanmıştır. Sonuç olarak bu ızgara vasıtasıyla daha önce görülmemiş yeni desenler kolaylıkla oluşturulabilir. Oluşturulan tüm desenler bu yöntemle istenilen ebatlarda herhangi bir yüzeye rahatlıkla uygulanabilir. Ayrıca bu ızgara büyütülerek daha karmaşık geometrik kompozisyonlar da çok daha pratik şekilde oluşturulabilir. 
Halil İbrahim ERYILMAZ, Bahar SELIMGIL

İslam Eserlerinde Kullanılan Altıgen Tabanlı Geometrik Desenlerin Çözümlenmesine Yönelik Yeni Bir Yaklaşım

\section{EK 1}

\begin{tabular}{|c|c|c|c|c|c|c|c|c|c|c|c|}
\hline \multicolumn{12}{|c|}{ Altıgen Tabanlı Geometrik Desenler (Coğrafi Bölgeye Göre) } \\
\hline & Grup & Fas & Hindistan & İngiltere & İran & İs panya & Misır & Özbekistan & Suriye & Türkiye & Toplam \\
\hline A11 & $1 \mathrm{a}$ & & 5 & 5 & 3 & & & 1 & 2 & 5 & 21 \\
\hline $\mathrm{A} 22$ & $1 \mathrm{~b}$ & & 1 & 1 & 1 & & & 2 & 1 & 1 & 7 \\
\hline A 31 & $2 \mathrm{a}$ & & & & & & & & & 3 & 3 \\
\hline A 33 & $2 \mathrm{~b}$ & & & & & & & & & 2 & 2 \\
\hline A 34 & $2 \mathrm{c}$ & & & & & & & & & 1 & 1 \\
\hline A411 & $3 a$ & & 19 & 1 & 2 & & 3 & 4 & 1 & 16 & 46 \\
\hline A416 & $3 b$ & & 1 & & & & & & & & 1 \\
\hline A411a & $3 \mathrm{c}$ & & & & & & 1 & & & & 1 \\
\hline A414 & $3 \mathrm{~d}$ & & & & & & & & & 1 & 1 \\
\hline A417 & $3 \mathrm{e}$ & & 2 & & & & & & & 1 & 3 \\
\hline A61 & $4 a$ & & & & & & & & & 3 & 3 \\
\hline A62 & $4 b$ & & & & & & & & & 4 & 4 \\
\hline $\mathrm{A} 62 \mathrm{a}$ & $4 c$ & & & & & & 1 & & 1 & 3 & 5 \\
\hline A621 & $5 \mathrm{a}$ & & 1 & 2 & & & 1 & & & & 4 \\
\hline $\mathrm{A} 622$ & $5 b$ & & & & 2 & & & & & 3 & 5 \\
\hline A623 & $5 \mathrm{c}$ & & 2 & 1 & & & 1 & & & 1 & 5 \\
\hline A711 & $6 a$ & & 6 & & & & & & & & 6 \\
\hline A 712 & $6 \mathrm{~b}$ & & 2 & 1 & & & 2 & & & 1 & 6 \\
\hline A713 & $6 c$ & & & & & & 1 & & & 2 & 3 \\
\hline A733 & $6 \mathrm{~d}$ & & 1 & & & & 4 & 1 & & 2 & 8 \\
\hline A734 & $6 e$ & & 3 & & & & & & & & 3 \\
\hline A714 & $6 \mathrm{f}$ & & 1 & & & & & & & 1 & 2 \\
\hline A716 & $7 \mathrm{a}$ & & & & & & 1 & & & & 1 \\
\hline A 721 & $7 \mathrm{~b}$ & 1 & 2 & & & 2 & & 1 & 3 & 4 & 13 \\
\hline A 722 & $7 \mathrm{c}$ & & & & & & & 3 & & & 3 \\
\hline A731 & $8 \mathrm{a}$ & 1 & & & & 1 & & & 1 & 1 & 4 \\
\hline A735 & $8 \mathrm{~b}$ & & & & & 1 & & & & & 1 \\
\hline A811 & $9 \mathrm{a}$ & & 7 & & 2 & & 1 & & & 5 & 15 \\
\hline A 812 & $9 \mathrm{~b}$ & & 5 & & & & & & & 1 & 6 \\
\hline A 821 & $10 \mathrm{a}$ & & & & & & 4 & & & 4 & 8 \\
\hline A 822 & $10 \mathrm{~b}$ & & 3 & & & & & & & 1 & 4 \\
\hline A 823 & $11 \mathrm{a}$ & 2 & & & & & & & & & 2 \\
\hline A 825 & $11 \mathrm{~b}$ & & 1 & & 1 & & & & & & 2 \\
\hline A831 & $12 \mathrm{a}$ & & 2 & & & & & & & 4 & 6 \\
\hline A 832 & $12 \mathrm{~b}$ & & & 1 & & & & & & 3 & 4 \\
\hline A 881 & $13 \mathrm{a}$ & & 1 & & & & & 1 & & 6 & 8 \\
\hline A 884 & $13 \mathrm{~b}$ & & & & & & & & & 1 & 1 \\
\hline A 883 & $13 \mathrm{c}$ & & & & & & & & & 2 & 2 \\
\hline A 882 & $13 \mathrm{~d}$ & & 1 & & & & 2 & & & & 3 \\
\hline & & 4 & 66 & 12 & 11 & 4 & 22 & 13 & 9 & 82 & 223 \\
\hline
\end{tabular}




\section{EK 2}

\begin{tabular}{|c|c|c|c|c|c|c|c|c|c|c|c|c|}
\hline \multicolumn{13}{|c|}{ Altıgen Tabanlı Geometrik Des enler (Kullanılan Malze meye Göre ) } \\
\hline & Grup & Ahşap & Çini & $\begin{array}{c}\text { Dekoratif } \\
\text { panel }\end{array}$ & $\begin{array}{c}\text { Mozaik } \\
\text { çini }\end{array}$ & $\begin{array}{c}\text { Renkli } \\
\text { taş } \\
\text { mozaik }\end{array}$ & Siva & $\begin{array}{c}\text { Taş } \\
\text { mozaik }\end{array}$ & Taş & Tezhip & Tuğla & Toplam \\
\hline A 11 & 1a & & & 1 & 13 & & 1 & 1 & 5 & & & 21 \\
\hline $\mathrm{A} 22$ & $1 \mathrm{~b}$ & & & & 4 & 1 & & & 1 & 1 & & 7 \\
\hline A31 & $2 a$ & & & & 3 & & & & & & & 3 \\
\hline A33 & $2 b$ & & & & 2 & & & & & & & 2 \\
\hline A 34 & $2 c$ & & & & 1 & & & & & & & 1 \\
\hline A411 & $3 \mathrm{a}$ & 3 & & 1 & 4 & 9 & 3 & 5 & 21 & & & 46 \\
\hline A416 & $3 b$ & & & 1 & & & & & & & & 1 \\
\hline A411a & $3 \mathrm{c}$ & & & & & & 1 & & & & & 1 \\
\hline A414 & $3 \mathrm{~d}$ & 1 & & & & & & & & & & 1 \\
\hline A417 & $3 e$ & 1 & & & & & & 1 & 1 & & & 3 \\
\hline A61 & $4 a$ & & & & & & 1 & & 2 & & & 3 \\
\hline A62 & $4 b$ & & & & 2 & & & 1 & & & 1 & 4 \\
\hline A62a & $4 c$ & & & & & 1 & & & 3 & & 1 & 5 \\
\hline A621 & $5 \mathrm{a}$ & & & & & & 1 & & 3 & & & 4 \\
\hline A622 & $5 b$ & & & & 2 & & 2 & & & & 1 & 5 \\
\hline A623 & $5 \mathrm{c}$ & & & & & 2 & & & 3 & & & 5 \\
\hline A711 & $6 \mathrm{a}$ & & & & & & 1 & & 5 & & & 6 \\
\hline A712 & $6 \mathrm{~b}$ & & & 1 & & 2 & 2 & & 1 & & & 6 \\
\hline A 713 & $6 c$ & & & & & & 1 & 1 & 1 & & & 3 \\
\hline A733 & $6 \mathrm{~d}$ & & & & 1 & 1 & 3 & & 3 & & & 8 \\
\hline A 734 & $6 e$ & & & & & & & & 3 & & & 3 \\
\hline A714 & $6 \mathrm{f}$ & 1 & & & & & & & 1 & & & 2 \\
\hline A716 & $7 \mathrm{a}$ & & & & & & 1 & & & & & 1 \\
\hline A 721 & $7 \mathrm{~b}$ & 2 & 1 & 3 & 1 & 1 & & & 4 & & 1 & 13 \\
\hline A 722 & $7 \mathrm{c}$ & 3 & & & & & & & & & & 3 \\
\hline A731 & $8 \mathrm{a}$ & 1 & 1 & & 1 & 1 & & & & & & 4 \\
\hline A 735 & $8 b$ & 1 & & & & & & & & & & 1 \\
\hline A811 & $9 \mathrm{a}$ & 2 & 1 & 2 & & 5 & 1 & & 4 & & & 15 \\
\hline A 812 & $9 \mathrm{~b}$ & & & 1 & & & & & 5 & & & 6 \\
\hline A 821 & $10 \mathrm{a}$ & 4 & & & & & 2 & & 2 & & & 8 \\
\hline A 822 & $10 \mathrm{~b}$ & & & & & & 1 & 1 & 2 & & & 4 \\
\hline A 823 & $11 \mathrm{a}$ & & & & 2 & & & & & & & 2 \\
\hline A 825 & $11 \mathrm{~b}$ & & & & 1 & & & 1 & & & & 2 \\
\hline A831 & $12 \mathrm{a}$ & & & 1 & 1 & & & & 4 & & & 6 \\
\hline A 832 & $12 \mathrm{~b}$ & 1 & & & 1 & & & 1 & 1 & & & 4 \\
\hline A 881 & $13 \mathrm{a}$ & 4 & 1 & & & & 1 & & 2 & & & 8 \\
\hline A 884 & $13 \mathrm{~b}$ & 1 & & & & & & & & & & 1 \\
\hline A 883 & $13 \mathrm{c}$ & & & 1 & & & & & 1 & & & 2 \\
\hline A 882 & $13 \mathrm{~d}$ & 1 & & & & & 1 & & 1 & & & 3 \\
\hline & & 26 & 4 & 12 & 39 & 23 & 23 & 12 & 79 & 1 & 4 & 223 \\
\hline
\end{tabular}


Halil İbrahim ERYILMAZ, Bahar SELIMGIL

İslam Eserlerinde Kullanılan Altıgen Tabanlı Geometrik Desenlerin Çözümlenmesine Yönelik Yeni Bir Yaklaşım

\section{EK 3}

\begin{tabular}{|c|c|c|c|c|c|c|c|c|c|c|c|c|c|c|c|c|}
\hline \multicolumn{17}{|c|}{ Altıgen Tabanlı Geometrik Desenler (Tarihsel Dönemlere Göre) } \\
\hline & Grup & 8.yy & 9.yy & 10.yy & 11.yy & $12 . y y$ & 13.yy & $\begin{array}{c}13- \\
15 . y y\end{array}$ & $14 . \mathrm{yy}$ & \begin{tabular}{|c|}
$14-$ \\
$15 . y y$
\end{tabular} & $15 . y y$ & 16.yy & 17.yy & 18.yy & $\begin{array}{c}\text { Dönemi } \\
\text { bilinme } \\
\text { yenler }\end{array}$ & Toplam \\
\hline A11 & la & & & & 1 & & 1 & & & 1 & 5 & 5 & 1 & 3 & 4 & 21 \\
\hline A22 & $1 \mathrm{~b}$ & & & & 2 & & 1 & & & & & & 3 & 1 & & 7 \\
\hline A 31 & $2 a$ & & & & & & & & & & 3 & & & & & 3 \\
\hline $\mathrm{A} 33$ & $2 \mathrm{~b}$ & & & & & & & & & & 2 & & & & & 2 \\
\hline $\mathrm{A} 34$ & $2 \mathrm{c}$ & & & & & & 1 & & & & & & & & & 1 \\
\hline A411 & $3 a$ & & 1 & 1 & & 2 & 4 & & 3 & 1 & 3 & 15 & 11 & 1 & 4 & 46 \\
\hline $\mathrm{A} 416$ & $3 \mathrm{~b}$ & & & & & & & & & & & & 1 & & & 1 \\
\hline A411a & $3 \mathrm{c}$ & & 1 & & & & & & & & & & & & & 1 \\
\hline A 414 & $3 d$ & & & & & & & & & & 1 & & & & & 1 \\
\hline A417 & $3 \mathrm{e}$ & & & & & & & & & & & 1 & 2 & & & 3 \\
\hline A61 & $4 \mathrm{a}$ & & & & & & 2 & & 1 & & & & & & & 3 \\
\hline $\mathrm{A} 62$ & $4 \mathrm{~b}$ & & & & & & 4 & & & & & & & & & 4 \\
\hline A62a & $4 c$ & & & & 1 & & 2 & & 1 & & & & & & 1 & 5 \\
\hline $\mathrm{A} 621$ & $5 \mathrm{a}$ & & & & & & & & & & & & 2 & & 2 & 4 \\
\hline A622 & $5 \mathrm{~b}$ & & & & 1 & & 1 & & 3 & & & & & & & 5 \\
\hline A623 & $5 \mathrm{c}$ & & & & & & 1 & & & & & & 3 & & 1 & 5 \\
\hline A711 & $6 \mathrm{a}$ & & & & & & 2 & & & & & 1 & & 1 & 2 & 6 \\
\hline A712 & $6 \mathrm{~b}$ & & 2 & & & & 1 & & & & & 2 & & & 1 & 6 \\
\hline A713 & $6 c$ & & 1 & & & 1 & 1 & & & & & & & & & 3 \\
\hline A733 & $6 \mathrm{~d}$ & & 3 & & & 1 & & & 2 & 1 & & & 1 & & & 8 \\
\hline A734 & $6 \mathrm{e}$ & & & & & & & & & & & 3 & & & & 3 \\
\hline A714 & $6 \mathrm{f}$ & & & & & & & & & & & 2 & & & & 2 \\
\hline A716 & $7 \mathrm{a}$ & & 1 & & & & & & & & & & & & & 1 \\
\hline A 721 & $7 \mathrm{~b}$ & 3 & & & & 1 & 2 & & 1 & 1 & 1 & & 1 & 2 & 1 & 13 \\
\hline A 722 & $7 \mathrm{c}$ & & & & & & & & & & 2 & & 1 & & & 3 \\
\hline A731 & $8 \mathrm{a}$ & & & & & & 2 & 1 & & & & & & & 1 & 4 \\
\hline A735 & $8 \mathrm{~b}$ & & & & & & & 1 & & & & & & & & 1 \\
\hline A811 & $9 \mathrm{a}$ & & & 1 & 2 & 1 & 1 & & & & 1 & 6 & 3 & & & 15 \\
\hline A 812 & $9 \mathrm{~b}$ & & & & & & & & & & & 6 & & & & 6 \\
\hline A 821 & $10 \mathrm{a}$ & & 2 & & & & 2 & & & & 4 & & & & & 8 \\
\hline A 822 & $10 \mathrm{~b}$ & & & & & & 1 & & & & & & & 3 & & 4 \\
\hline A 823 & $11 \mathrm{a}$ & & & & & & & & & & & & & & 2 & 2 \\
\hline A 825 & $11 \mathrm{~b}$ & & & & 1 & & & & & & & & 1 & & & 2 \\
\hline A831 & $12 \mathrm{a}$ & & & & & & 3 & & 1 & & & & 1 & 1 & & 6 \\
\hline A 832 & $12 \mathrm{~b}$ & & & & 1 & & 1 & & & & & 1 & & & 1 & 4 \\
\hline A881 & $13 a$ & & & & & & & & 1 & & 1 & 5 & & & 1 & 8 \\
\hline A884 & $13 \mathrm{~b}$ & & & & & & 1 & & & & & & & & & 1 \\
\hline A883 & $13 \mathrm{c}$ & & & & & & & & & & 1 & 1 & & & & 2 \\
\hline A882 & $13 \mathrm{~d}$ & & & 2 & & & & & & & & & & & 1 & 3 \\
\hline & & 3 & 11 & 4 & 9 & 6 & 34 & 2 & 13 & 4 & 24 & 48 & 31 & 12 & 22 & 223 \\
\hline
\end{tabular}




\section{Kaynakça}

Arık Metin, Mustafa Sancak, Pentapleks Kaplamalar, Ankara:Tübitak Kitaplar Müdürlüğü, 2012.

Ayvazoğlu, Beşir, Aşk Estetiği. İstanbul: Ötüken Yayınları, 2000.

Baydemir, Tuncay. Çizge Teorisi. Bilim ve Teknik Dergisi, 54 (2020):26.

Çaycı, Ahmet, İslam Mimarisinde Anlam ve Sembol, Konya: Palet Yayınları, 2017.

Ekizler, Sönmez Serap. Mimar Sinan Camileri ve İlam Sanatında Geometrik Desenler. İstanbul: Klasik Yayınları, 2017.

Demiriz, Yıldız. İslam Sanatında Geometrik Süsleme. İstanbul: Hayalperest Yayınevi, 2017.

Eric, Broug. İslam Sanatında Geometrik Desenler. İstanbul: Klasik Yayınları, 2016.

Kuban, Doğan, Türk ve İslam Sanatı Üzerine Denemeler. İstanbul: Arkeoloji ve Sanat Yayınları, 2015.

Leaman, Oliver, İslam Estetiğine Giriş. İstanbul: Küre Yayınları, 2019.

Mülayim, Selçuk, Anadolu Türk Mimarisinde Geometrik Süslemeler-Selçuklu Çağı. Ankara: Kültür Bakanlığı Yayınları, 1982.

Mülayim, Selçuk, Geometrik Kompozisyonların Çözümlenmesine Bir Yaklaşım. Sanat Tarihi Dergisi, 1(1982):1.

Mülayim, Selçuk, Değişimin Tanıkları Ortaçağ Türk Sanatında Süsleme ve İkonografi. İstanbul: Kaknüs Yayıncılık, 1999.

Necipoğlu, Gülru. The Topkapı Scroll-Geometry and Ornament in Islamic Architecture. New York: The Getty Center, 1995.

Ögel, Semra, Anadolu Selçuklu Sanatı Üzerine Görüşler. İstanbul: Matbaa Teknisyenleri Basımevi, 1986.

Öney, Gönül. Anadolu Selçuklu Mimari Süslemesi ve El Sanatları. Ankara: Türkiye İş Bankası Kültür Yayınları, 1992.

Özgür, Şenay, "İslam Sanatında Geometrik Süslemenin Ardındaki Matematik." XI. Ortaçag-Türk Dönemi Kazı Sonuçları ve Sanat Tarihi Araştırmaları Sempozyumu Kitabı içinde. Bu bildiri, 17-19 Ekim 2007 tarihleri arasında XI. Ortaçag-Türk Dönemi Kazı Sonuçları Ve Sanat Tarihi Araştırmaları Sempozyumu'nda sunulmuştur. İzmir: Ege Üniversitesi Basımevi, 2009.

Sudeysi Muhammed, “Hendese”, Türkiye Diyanet Vakfı İlam Ansiklopedisi, 17 (İstanbul: Diyanet Vakfı Yayınları, 1998), 196-199.

Şen Hüseyin, "İslam Sanatında Geometrik Desenler," Türk-Islam Medeniyeti Akademik Araştırmalar Dergisi,8 ( 2013):105-112.

Erişim 7 Ocak 2021. https://patterninislamicart.com/archive/main

Erişim 7 Ocak 2021. http://www.mustafacambaz.com

Erişim 7 Ocak 2021. https://pbase.com/dosseman

Erişim 7 Ocak 2021. http://www.selcuklumirasi.com/architectural-buildings 